University of Konstanz

Department of Economics

\title{
Is German Domestic Social Policy Politically Controversial?
}

Niklas Potrafke

Working Paper Series

2011-06 


\title{
Is German domestic social policy politically controversial?
}

\author{
Niklas Potrafke ${ }^{1}$ \\ University of Konstanz
}

This version: April 26, 2011

\begin{abstract}
This paper investigates empirically the influence of government ideology on social policy using German data. Examining the funding and the benefits of social security and public healthcare policy, my results suggest that policies implemented by governments dominated by left- and rightwing parties were similar over the 1951-2007 period. Leftwing governments, however, spent more in the 1970 s and rightwing governments did so after German Reunification in 1990. Since policy convergence encourages new parties to enter the political arena, and party platforms on social policy matters are likely to undergo further changes in light of demographic change, the observed pattern may thus be a transitory phenomenon.
\end{abstract}

Keywords: social policy, political business and partisan cycles, government ideology, policy polarization, demographic change

JEL Classification: H52, H55, I38, J18, D72

\footnotetext{
${ }^{1}$ University of Konstanz, Department of Economics, Box 138, D-78457 Konstanz, Germany, Phone: +497531 88 2137, Fax: + 49753188 3130. Email: niklas.potrafke@uni-konstanz.de
} 


\section{Introduction}

Social policy has always been controversial. Leftist governments have raised welfare spending whereas market-oriented governments have tried to follow a policy of retrenchment. Despite the (at least rhetorical) efforts of the political right, welfare expenditures, especially spending on public pensions and health care, have increased dramatically over the last decades in industrialized countries. One is tempted to conjecture that political parties and selfinterested incumbents have used the keen public interest in social policy to gratify their clienteles and to improve their re-election prospects by increasing welfare expenditures before elections.

This conjecture needs to be examined more rigorously. To be sure, some related empirical studies have examined social expenditures or benefit rates (e.g., Hicks and Swank 1992; Moene and Wallerstein 2001; Kittel and Obinger 2003; Potrafke 2009a; Korpi and Palme 2003; Allan and Scruggs 2004; Congleton and Bose 2010). ${ }^{2}$ These studies have used panel data, which has the advantage of exploiting variation across countries and over time. But using panel data is also problematic for two reasons. The first problem is that institutional characteristics of the social insurance system differ across countries. For example, in federal states such as Germany, both parliamentary chambers decide on social policy. When political majorities in the two chambers differ, governments are not always able to implement their preferred policies. Indicators of political constraints, which have often been employed in panel data studies, track these institutional characteristics only to a limited extent. The second problem is that panel data studies cover fairly short sample periods because the data need to be comparable across countries. Yet the availability of comparable data is limited. The OECD has, for example, compiled data on social expenditures for industrialized countries (Social Expenditure Database - SOCX). In doing so, it had to address a number of methodological,

\footnotetext{
${ }^{2}$ Congleton and Shughart (1990) investigate political economic determinants of the growth of social security retirement benefit levels in the United States over the 1946-1982 period, but do not consider government ideology and electoral motives.
} 
classification and data issues. Consequently, the recent SOCX covers only the 1980-2005 period.

The advantage of a country-based study is to avoid the problems that are inherent in a panel data study. The inferences drawn from such a case study can then be transferred to other industrialized countries with similar institutions.

Germany is a particularly interesting case for two reasons. The first social insurancesystem was created in Germany in the 1880s (e.g., Cutler and Johnson 2004) and institutional characteristics have not changed significantly since the 1950s. Second, many observers believe that party and policy polarization between the dominant parties in Germany, the Social Democratic Party (SPD) and the Christian Democratic Party (CDU/CSU), have nearly disappeared (e.g., Seeleib-Kaiser et al. 2008). Moreover, some empirical studies show that government ideology has not played a substantial role in German economic policy (e.g., De Haan and Zelhorst 1993, Potrafke 2009b). Case studies show that social policies of the SPD and CDU/CSU have been similar (e.g., Alber 1989, van Kersbergen 1995, Schmidt 2005). In contrast to fiscal and monetary policy, scholars have not employed econometric models to examine whether government ideology and electoral motives influenced German social security policy and healthcare policy. I acknowledge that Schmidt (1992) found that total social expenditures were significantly lower under rightwing than under leftwing German governments over the 1951-1988 period. Considering that social security and healthcare policy have become more important in the public and academic debate, the lack of scholarly analyses of ideology-induced German social security and healthcare policies is a surprising omission.

In order to assess the extent to which social policy is politically controversial, this paper investigates empirically the influence of government ideology on social policy using German data. The advantage of a country study is to hold constant a variety of institutional characteristics and to be able to investigate a fairly long time period. Country studies thus 
complement nicely the more often used panel studies. Examining the funding and the benefits of German social security and public healthcare policy, my results suggest the following:

1. Policies implemented by the two leading parties were similar over the 1951-2007 period. However, leftwing governments spent more in the 1970s and rightwing governments spent more after the German Unification in 1990. This finding corresponds with case study evidence on social policies in Germany and panel data studies on ideology-induced social policies in OECD countries.

2. In the first years after the German Unification, then-chancellor Helmut Kohl prioritized sociopolitical objectives and associated transfer payments to the East Germans, whereas Christian Democratic beliefs favoring a smaller governmental role in the economy retired to the background.

3. When the leftwing SPD and the conservative CDU formed a joint coalition they lowered social expenditures because they had no political advantage from being more generous.

4. The German case appears to be a prime example of the fact that policy convergence among established leftwing and rightwing parties opens some space at the tails of the political spectrum: in 2007, for example, the socialist party "DIE LINKE" was founded to provide socialist political platforms. One of the reasons for this was that the SPD had moved to the political center.

5. Convergence in social policy appears to be a transitory phenomenon. The first clues transpired in 2010: the SPD, at this time the largest opposition party, was against an official retirement age of 67 , although the SPD advocated an official retirement age of 67 when they formed a coalition with the CDU/CSU during 2005-2009. Party platforms on social security and public health matters are likely to be reversed in light of demographic changes and social policy is therefore also likely to become more controversial again. 
The paper is organized as follows: Section 2 discusses the theoretical and empirical literature on government ideology in German economic policy and derives the hypotheses to be tested. Section 3 presents the econometric analysis: it summarizes the institutional background, the data and variables included, specifies the empirical models and discusses the results. Section 4 concludes.

\section{Theoretical background and related empirical literature}

\subsection{Ideology-induced macroeconomic policies in Germany}

The political business cycle and partisan theories seek to explain how politicians influence economic outcomes. One implication of the political business cycle models is that all politicians will implement the same expansionary economic policy before elections. In other words, political ideology retires to the background, and policies converge. Theories of political business cycles can be distinguished in models assuming adaptive (Nordhaus 1975) and rational expectations (Rogoff and Sibert 1988, Rogoff 1990) of economic actors. In any event, this distinction does not affect the final result of boosting the economy before elections to increase politicians' chances of reelection. The partisan approach focuses on the role of party ideology and shows the extent to which leftwing and rightwing politicians can pursue different policies that reflect the preferences of their partisan constituencies. A leftist party appeals more to the labor base and promotes expansionary policies, whereas a rightwing party appeals more to capital owners, and is therefore more concerned with reducing inflation. This pattern holds for both branches of the partisan theory - for the classical approach (Hibbs 1977) and for the rational approach (Alesina 1987). Many empirical studies have investigated how electoral motives and government ideology influence economic outcomes (see, for example, Alesina et al. 1997, Cusack 1997, Schmidt 2002, Grier 2008, Belke et al. 2007, Bjørnskov 2008, Sakamoto 2008, Bodea 2010, Aidt et al. 2011, Broz 2011). 
In Germany, inflation has been higher under leftwing than under rightwing governments. Unemployment, however, has either been extremely low or extremely high under rightwing governments. Belke $(1996,2000)$ examines partisan cycles in unemployment and inflation and introduces a hysteresis-augmented rational partisan theory.

As to German fiscal policy, government ideology did not influence fiscal indicators such as government debt (De Haan and Zelhorst 1993, Berger and Woitek 1997a, Potrafke 2009b), overall government spending, and tax revenues (Koester 2009, Potrafke 2009b), but government ideology did affect the allocation of public expenditures at the federal level (Bawn 1999, König and Tröger 2005, Potrafke 2009b). Taxes were reduced somewhat before elections (Koester 2009). In the German Laender, government ideology also does not appear to have systematically influenced overall government expenditures, public debt and revenues, but electoral and partisan effects helped shaping budget composition (see, for example, Seitz 2000, Berger and Holler 2007, Schneider 2010, Galli and Rossi 2002, Oberndorfer and Steiner 2007, Potrafke 2011). ${ }^{3}$

With respect to German monetary policy, the growth of monetary aggregates appears to increase before elections and decline afterwards when the federal government had a majority in the Bundesbank council at the beginning of the pre-election period or when the political majority changed in favor of the federal government during the pre-election period (Vaubel 1997a, 1997b and Berger and Woitek 1997a, 1997b). ${ }^{4}$ Politicians do not influence monetary aggregates directly, due to institutional restrictions, most notably central bank independence (the German Bundesbank has enjoyed a high degree of independence since the 1950s). For this reason, electoral motives and government ideology are likely to influence monetary policy only when central banks are less independent and subject to directives of the

\footnotetext{
${ }^{3}$ The results of Tepe and Vanhuysse (2009a) show that incumbents accelerated the hiring of new teachers before elections in the German Laender.

${ }^{4}$ See also Lohmann (1998), Vaubel (1999) and Berger and Woitek (2001, 2005).
} 
government. In any event, government ideology has an influence on appointments to the council of the central bank. A political party may tend to nominate council members with political preferences similar to its own (Vaubel 1993, 1997a). The nominated council members, in turn, may be loyal to the party that has appointed them (Goehlmann and Vaubel 2007). ${ }^{5}$

\subsection{Government ideology and social policy}

Leftist governments traditionally have increased welfare spending: panel data studies for OECD countries suggest that leftist governments increased such public expenditures until the beginning of the 1990s (e.g., Hicks and Swank 1992, Moene and Wallerstein 2001, Kittel and Obinger 2003, Korpi and Palme 2003, Allan and Scruggs 2004). ${ }^{6}$ Policy differences between leftwing and rightwing parties converged because all parties had to implement some retrenchment relative to the 1960-1980s period (e.g. Huber and Stephens 2001, Pierson 1996 and 2001). ${ }^{7}$ Yet partisan politics disappeared in the 1990s, though not because of globalization (Potrafke 2009a). The absence of ideology-induced effects on the aggregate of social expenditures does not, however, imply that the composition of the budget remained unaffected by government ideology. Decomposing social expenditures and focusing on subcategories, such as social security and health expenditures, may identify compensating effects and is therefore a promising avenue of research (see, for example, Busemeyer et al. 2009).

\footnotetext{
${ }^{5}$ Government ideology also influenced stock market performance in Germany: the mean and the volatility of the returns to the defense and pharmaceutical sectors increased if a rightwing government became more likely to win the upcoming federal election. By contrast, the returns to alternative energy sector stocks and the volatility of consumer sector returns increased if a leftwing government was likely to win the upcoming federal election (Bechtel and Füss 2010). Higher small-firm stock returns and larger volatility have been linked to the probability of a rightwing government winning the election (Füss and Bechtel 2008).

${ }^{6}$ The results of Iversen and Soskice (2001) suggest that the support of rightwing parties and the support for social spending is negatively associated.

${ }^{7}$ The results reported by Le Maux et al. (2011) show that a large electoral margin and a low fragmentation of leftwing majorities had a positive influence on per capita social expenditures in French departments.
} 
Formal models that explain the interaction of government ideology or electoral motives and social security and healthcare policy apparently do not appear to exist. Many scholars, however, illustrate the role of government in social security and healthcare politics. The model of De Donder and Hindriks (2007) portrays the interaction of a leftist and a rightwing party in designing a social insurance system and predicts that the leftwing party proposes more social insurance than the rightwing party. The rightwing party attracts the richer voters, and voters with lower health risks, and the leftwing party attracts the poorer voters, and voters with higher health risks.

The partisan approach initially implies that leftwing governments will increase social security coverage. Rightwing governments, however, are also likely to put emphasis on social security because an important part of conservative parties' constituencies are pensioners (e.g., van Kersbergen 1995). For this reason, one may well expect no ideology-induced effects on pension benefits. The results of Tepe and Vanhuysse (2009b: footnote 5), for example, suggest that government ideology did not influence pension expenditures in OECD countries. In contrast, government ideology is likely to affect the funding of social security insurance. For example, rightwing governments will favor low ancillary labor costs and will therefore try to keep individual contributions to the social insurance program low, but favor financing larger public pension benefits via tax-financed subsidies.

In line with the partisan approach, leftist governments are expected to expand the role of government in healthcare policy. Immergut (1992: 1) describes how politicians implement different healthcare policies and comes to the following conclusion: „National health insurance symbolizes the great divide between liberalism and socialism, between the free market and the planned economy....Political parties look to national health insurance programs as a vivid expression of their distinctive ideological profiles and as an effective means of getting votes... National health insurance, in sum, is a highly politicized issue." 
By contrast, Jensen (2011a) argues that in modern welfare states, both leftwing and rightwing parties expand public health spending. While previous studies have established theories as to how leftwing governments extend the public health system and considered rightwing governments only as counterparts to leftwing governments, Jensen (2011a) develops a theory of how rightwing governments implement healthcare policies. Rightwing governments face the following dilemma: they need to balance the pro-social-safety-net preferences of middle-class voters against the preferences of the pro-private-pension preferences of high-income voters. Moreover, in almost all industrialized countries except the United States, compulsory public health systems have been established. A majority of the voters appears strictly to be against severe budget cuts for the public health system. Rightwing governments are expected to solve this dilemma by a strategy called "marketization via compensation". This strategy consists of two components. First, rightwing governments match the healthcare policies of the political left and keep public spending at quite generous levels. Second, rightwing governments actively encourage and financially support private alternatives to health care, such as making so-called catastrophic insurance more widely available. The empirical results reported by Jensen (2011a, 2011b) and Potrafke (2010) show that government ideology has not influenced public health expenditures in OECD countries, but that electoral motives do (Potrafke 2010).

Institutional constraints, such as interest-group influence, constitutional checks and balances and divided government, are likely to counteract ideology-induced and electionmotivated effects on social policy. ${ }^{8}$ For this reason, partisan politicians will implement their preferred policies incrementally, step-by-step over the legislative period. It is not likely that a newly elected government can pursue its most preferred policies from the beginning of the legislative period. This suggests investigating the influence of government ideology and

\footnotetext{
${ }^{8}$ Firms in the financial market may, for example, lobby the government to lower compulsory contributions to the public pension system (Kemmerling and Neugart 2009).
} 
electoral motives on the changes on social policy. The hypotheses to be tested are the following:

1. The growth rate of revenues from contributions to social security insurance is faster under leftwing than rightwing governments.

2. The growth rate of revenues from tax-financed subsidies to social security insurance is lower under leftwing than rightwing governments.

3. The growth rate of pension benefits is not influenced by government ideology.

4. The growth rate of healthcare benefits is faster under leftwing than rightwing governments.

5. In election years, self-interested politicians raise the growth rate of tax-financed subsidies to the social security insurance, public pension benefits, and public healthcare benefits, and decrease the growth rate of individual contributions to social security.

\section{Empirical political economic analysis of German social policy}

\subsection{Institutional background}

Germany is a federal state. In principle, Germany's constitution (Art. 30 and Art. 70 I) states that as many responsibilities as possible should reside in the states (German Laender). De facto, however, the federal government has had by far the greatest authority (e.g., Blankart 2008: Chapter 28, Blankart 2007: Chapter 7). The federal level clearly dominates the important policy fields of social welfare and social insurance (Seitz 2008).

The German states may influence federal policies by acting through the second parliamentary chamber (Bundesrat). Federal amendments require confirmation by the second chamber when they also concern matters of the states (Art. 84 Abs. 1 GG). In social policy, this aspect relates to healthcare matters more than to social security matters. The reason is that federal governments may modify legislative proposals affecting social security such that they 
do not require amendments by the second chamber (for example, in 2001, the "Altersvermögensergänzungsgesetz" did not require a vote by the second chamber, whereas the "Altersvermögensgesetz" did). In contrast, administrative procedures and adjustments of government agencies concerning healthcare policy issues mostly concern matters of the states (e.g., hospital arrangements). De facto, all decisive health amendments required confirmation by the second chamber until the reform of fiscal federalism in 2006. For this reason, divided government and checks and balances that may lead to policy convergence (Alesina and Rosenthal 1996) concern health care more than social security.

The German public pension system is a Bismarckian: pension benefits and individual contributions are closely related. Intragenerational redistribution hardly occurs in the German public pension system. Revenues from contributions, however, did not cover all pension benefits during the last decades, and tax-financed subsidies to the German public pension system have increased to cover the expenses. The German pension insurance is compulsory for blue collar and white collar workers alike. In 2007, the German Pension Insurance had 31.5 million insureds (out of about 82 million German inhabitants).

Public health insurance is compulsory in Germany. The German government regulates preferred-risk premiums and prohibits insurers from charging risk-based premiums. Insurers need to accept any applicant under an open enrollment policy (see, e.g., Breyer et al. 2009). Citizens with income above a certain threshold (48.600 Euros gross income in 2009) can choose private insurance. Citizens below this income threshold are coverd by the public health insurance program. In 2007, public health insurance enrolled about 50.7 million participants. The public health insurance was financed exclusively by individual contributions to it until 2004. As a result, health insurance premiums had to be raised immediately whenever expenditures for healthcare benefits increased. 


\subsection{Data and variables}

I use data on revenues from contributions and tax-financed subsidies to the German public pension system and data on expenditures for pension benefits provided by the German Pension Insurance and data on public health expenditures provided by the German Federal Ministry of Public Health. The observation period runs from 1957 to 2007 for the social security indicators and from 1951 to 2007 for expenditures on healthcare benefits (in levels). I define the social security indicators as shares of GDP and the public health insurance expenditures per enrolled member. I do not employ revenues from contributions to the health insurance program because - in contrast to the German public pension insurance - all public healthcare benefits must be financed by revenues from contributions. Tax-financed subsidies to the German public health insurance were not allowed for a long time. ${ }^{9}$ After German Reunification in October 1990, East Germans were integrated into the former West German system, and therefore the data contain structural breaks. For the period until 1990 I employ the former West German data, and for the 1991-2007 period I employ the data for the entire nation. I include a dummy variable to control for this structural break.

Figure 1 illustrates that revenues from contributions to the German Pension Insurance fund (as a share of GDP) increased from $4.5 \%$ in 1957 to $7.2 \%$ in 2007 . Revenues from taxfinanced subsidies to the same program (as a share of GDP) increased from $1.6 \%$ in 1957 to $2.3 \%$ in 2007 . The growth in revenues from tax-financed subsidies increased markedly after 1990 (I examine the sum of the tax-financed subsidies and the so called "extra tax-financed subsidies" in the 1998-2007 period). The expenditures of the German Pension Insurance system (as a share of GDP) increased from $4.9 \%$ in 1957 to $8.3 \%$ in 2007 . It is important to note that I employ expenditures on pension benefits only, not the total expenditures of the fund, which also include, e.g., administrative costs. This is why the sum of revenues from contributions and revenues from tax-financed subsidies exceeds pension benefits. Figure 2

\footnotetext{
${ }^{9}$ In 2007, the so called "health fund" and also tax financed subsidies to the fund were introduced.
} 
shows that public healthcare benefits (per member of the public health insurance system, in real terms) dramatically increased from 16.97 Euros in 1951 to 3199.65 Euros in 2007. The dramatic rise began in 1970 when the Social Democrats were elected after the grand coalition of the 1967-1969 period.

Unit root tests show that the time series described in Figures 1 and 2 are nonstationary in levels but stationary in growth rates. ${ }^{10}$ I employ the growth rates of social security and public healthcare benefit indicators in my econometric models to avoid spurious regression.

\section{The German political party landscape}

Two major political parties have dominated the political spectrum in Germany: the leftist Social Democratic Party (SPD) and the conservative Christian Democratic Union (CDU). In Bavaria, Germany's largest federal state by area, the conservatives are not represented by the CDU but by their sister party, the Christian Social Union (CSU). No party competition emerges between the CDU and the CSU and they form a single faction in the federal parliament (Bundestag). This is why I label both as CDU in the empirical analysis. All federal chancellors were members of one of these two major blocs, SPD and CDU. Therefore, one can test for ideology-induced effects on this left-right dimension.

The much smaller Free Democratic Party (FDP) and Green party (GREEN) have played an important role as coalition partners. While the SPD has formed coalitions with all three other parties, the CDU never formed a coalition with the Greens at the federal level. I will also consider the influence of the different coalition types, because the left-right dimension may neglect ideological differences between government parties within a "camp" (for the Left between SPD/FDP and SPD/GREEN coalitions).

\footnotetext{
${ }^{10}$ I have employed unit root tests to address the structural break because of the German Unification (Perron 1989, 1990, Saikkonen and Lütkepohl 2002, Lanne et al. 2002). I have included a shift dummy in the test regressions with levels and an impulse dummy in the test regressions with growth rates (see also Potrafke 2009 b). All results are available on request.
} 


\subsection{The econometric models}

The basic empirical social security models have the following form:

$\Delta \ln$ 'Social security indicator' ${ }_{\mathrm{jt}}=\alpha$ Election $_{\mathrm{t}}+\Sigma_{\mathrm{k}} \beta_{\mathrm{k}}{ }^{\text {'Ideology' }}{ }_{\mathrm{kt}}+\Sigma_{\mathrm{l}} \gamma_{1} \Delta \ln \mathrm{X}_{\mathrm{lt}}$

$+\delta$ Linear time trend $+\varepsilon$ German Unification Dummy ${ }_{\mathrm{t}}+\lambda+\mathrm{u}_{\mathrm{jt}}$

with $\mathrm{j}=1, \ldots, 3 ; \mathrm{k}=1, \ldots, 3^{11} ; \mathrm{l}=1, \ldots, 3$

where the dependent variable $\Delta \ln$ 'Social security indicator' ${ }_{\mathrm{jt}}$ denotes the growth rate of social security indicator $\mathrm{j}$ (as a share of GDP): contributions to the German Pension Insurance fund, revenues from tax-financed subsidies to the same program, expenditures of the German Pension Insurance fund on pension benefits. Election $\mathrm{t}_{\mathrm{t}}$ describes an election-year variable. $\Sigma_{\mathrm{k}}$ $\beta_{\mathrm{k}}$ 'Ideology' ${ }_{\mathrm{ikt}}$ describes the ideological orientation of the respective government. Below, I describe the election and ideology variables and their coding in detail. $\Sigma_{1} \beta_{1} \Delta \ln \mathrm{X}_{\mathrm{ilt}}$ contains three exogenous control variables (as well as a constant). I follow the related literature by including the growth in the unemployment rate $(\Delta \ln$ 'Unemployment' $t)$, the growth rate of real compensation per employee ( $\Delta \ln$ 'Compensation of Employees' $\mathrm{t}$ ) and the growth rate of the dependency ratio $(\Delta \ln$ 'Dependency ratio' $)$. Thus, conditions in the labor market, the earnings of employees and demographic change are taken into account. I include a linear time trend to address Wagner's Law predicting that the development of an industrialized economy will be accompanied by a rise in the share of public expenditure in GDP. 'German Unification Dummy $_{t}{ }^{\prime}$ is a dummy variable that takes on the value 1 in the year 1991 and is 0 otherwise. This coding implies that a level shift occurred in $1991 .^{12} \lambda$ is a constant, $\mathrm{u}_{\mathrm{jt}}$ is an error term. It is important to note that the level of the dependent variable is expressed in GDP shares, so

\footnotetext{
${ }^{11}$ The number of $\mathrm{k}$ depends on the specification (see below).

${ }^{12}$ Alternatively, I include a dummy variable that takes on the value 1 in the 1991-2007 period and the value 0 in the 1958-1990 period (see the robustness test section). The alternative coding implies that a shift in the growth rate after 1991 occurred.
} 
that deflating is not an issue. To preempt any concerns that inferences regarding the political variables are driven by including/excluding the control variables, I will also present results where only political variables are entered.

The basic empirical healthcare benefit model has the following form:

$$
\begin{aligned}
& \Delta \ln \text { 'Healthcare benefits' }{ }_{\mathrm{t}}=\alpha \text { Election }_{\mathrm{t}}+\Sigma_{\mathrm{k}} \beta_{\mathrm{k}}{ }^{\prime} \text { Ideology' }_{\mathrm{kt}} \\
& +\gamma \text { Divided government dummy }_{\mathrm{t}} \\
& +\Sigma_{1} \delta_{1} \Delta \ln \mathrm{X}_{\mathrm{lt}}+\varepsilon \text { German Unification Dummy }{ }_{\mathrm{t}}+\lambda+\mathrm{u}_{\mathrm{t}}
\end{aligned}
$$

with $\mathrm{k}=1, \ldots, 3^{13} ; \mathrm{l}=1, \ldots, 4$

where the dependent variable $\Delta \ln$ 'Healthcare benefits' ${ }_{t}$ denotes the growth rate of healthcare benefits per member of the German health insurance in constant prices. Election $\mathrm{t}_{\mathrm{t}}$ describes an election-year variable. $\Sigma_{\mathrm{k}} \beta_{\mathrm{k}}$ 'Ideology' ${ }_{\mathrm{kt}}$ describes the ideological orientation of the respective government. In the next paragraph I describe the election and ideology variables and their coding in detail. The 'divided government' dummy is a binary variable that takes on the value 1 when the governing parties at the federal level did not have a majority in the second chamber (Bundesrat). This variable is coded based on the dataset of Leunig and Bauer (2006). ${ }^{14} \Sigma_{1} \beta_{1} \Delta \ln \mathrm{X}_{\mathrm{ilt}}$ contains four exogenous control variables (as well as a constant). I follow the related literature by including the growth rate of GDP per member of German health insurance ( $\Delta \ln$ 'GDP per member' $)$, the growth rate of the dependency ratio $(\Delta \ln$

\footnotetext{
${ }^{13}$ Subscript $\mathrm{k}$ again depends on the specification (see below).

${ }^{14}$ Government was divided in 1951-1961. The conservative federal government had a majority in the second chamber in the 1962-1966 period. In times of the grand coalitions, 1967-1969 and 2006-2007, the SPD and the CDU had the majority in the second chamber. The times of a grand coalition, however, are not located on the left-right scale. The SPD/FDP coalitions never had a majority in the 'Bundesrat' untill 1982. The CDU/FDP government had a majority in the 1983-1989 period. From 1990 to 2005, government was divided again. This coding implies that only conservative federal governments had majorities in the second chamber for some timeperiods. Leftwing federal governments, however, never had a majority in the second chamber. For this reason, one cannot interact the left-right dummy variable with the divided government variable to examine whether ideology-induced effects were smaller with divided governments.
} 
'Dependency ratio' $)$, the growth in the mortality rate $(\Delta \ln$ 'Mortality rate' $t)$ and the growth rate of a linear time trend $\left(\Delta \ln\right.$ 'Linear time trend' $\left.{ }_{t}\right)$. The linear time trend approximates technological progress (Breyer and Ulrich 2000). The linear time trend (in levels) is expected to influence the level of healthcare benefits. This is why I regress the growth rate of healthcare benefits on the growth rate of the linear time trend. ${ }^{15}$ The 'German Reunification' dummy is coded in the same way as above. $\lambda$ is a constant, $u_{t}$ is an error term.

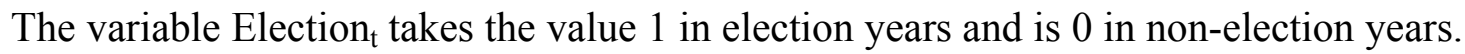
I discuss alternative codings in the robustness checks reported below.

The differences between leftist and rightwing governments will be tested on the leftright scale using the variable "Left" as well as different coalition type dummies, respectively. The dummy variable "Left" takes on the value 1 in periods when a SPD chancellor was in office (excluding grand coalitions) and 0 otherwise. ${ }^{16}$ In the alternative specification, the coalition type dummy variables take on the value 1 when a given coalition type was in power and 0 otherwise. I distinguish between four different coalition types that governed at the German federal level: CDU/FDP, CDU/SPD, SPD/FDP, and SPD/GR. ${ }^{17}$ To avoid pefect collinearity between the coalition type dummies, one of the coalition type dummies must function as the reference category (here CDU/SPD). The estimated effects of the other coalition type dummies must then be interpreted as deviations from the reference category. In fact, regressing the growth rate of the expenditure categories on the government ideology dummies implies that leftist and rightwing governments implement their preferred policies incrementally. Table A1 provides descriptive statistics for all variables.

\footnotetext{
${ }^{15}$ The linear time trends have different meanings in equations (1) and (2): addressing Wagner's law in equation (1) and the technological progress in equation (2). This is why the linear time trend is included in levels in equation (1) and in growth rates in equation (2). In any event, this matter of specification does not influence the inferences regarding the political variables.

${ }^{16}$ There were grand coalitions at the federal level in the 1967-1969 period and the 2006-2009 period.

${ }^{17}$ In the first legislative periods after 1949 smaller parties were also part of the coalition governments. I follow the related empirical literature that subsumes the 1949-1966 period as a period governend by the CDU/FDP.
} 
I now turn to discussing my choice of estimation methods. I employ the generalized least squares method to estimate the parameters in a linear regression model in which the error terms are serially correlated, because the Durbin Watson test rejects the null hypothesis of no serial correlation in the errors terms (Prais-Winsten estimator with robust standard errors). Serial correlation in particular occurs in the equation with tax-financed subsidies to the social security system. I also discuss results with ordinary least squares (OLS) and robust standard errors.

\subsection{Regression Results}

Table 1 reports the regression results for the social security policies when the ideologyinduced effects are evaluated on the left-right-scale by the variable "Left". Columns (1) to (3) do not include the control variables in order to show that including/excluding the control variables does not change the inferences regarding the political variables. The control variables in columns (4) to (6) mostly display the expected signs and indicate well-specified empirical models. For example, the compensation of employees has had a positive influence on the revenues from contributions (column 4). The coefficient is statistically significant at the $10 \%$ level and indicates that revenues from contributions (as a share of GDP) increased by about $0.29 \%$ when the compensation of employees increased by $1 \%$. The Unification Dummy is statistically significant at the $1 \%$ level in column (4) and indicates that the growth rate of revenues from contributions increased by about 2.8 percentage points in the year after the German Unification. The unemployment rate, the dependency ratio and the linear time trend do not turn out to be statistically significant in column (4). The unemployment rate has the expected positive influence on revenues from tax-financed subsidies (column 5). The coefficient of the unemployment rate is statistically significant at the $1 \%$ level and indicates that revenues from tax-financed subsidies (as a share of GDP) increased by about $0.20 \%$ when the unemployment rate increased by $1 \%$. The dependency ratio turns out to be statistically 
significant at the $10 \%$ level and indicates that revenues from tax-financed subsidies (as a share of GDP) increased by about $0.89 \%$ when the dependency ratio increased by $1 \%$. The Unification Dummy is statistically significant at the $10 \%$ level in column (5) and indicates that the growth rate of revenues from tax-financed subsidies (as a share of GDP) increased by about 10.2 percentage points in the year after the German Unification. The compensation of employees and the linear time trend do not turn out to be statistically significant at conventional levels in column (5). Pension benefits increased with the unemployment rate (column 6). The coefficient of the unemployment rate is statistically significant at the $1 \%$ level and indicates that pension benefits (as a share of GDP) increased by about $0.10 \%$ when the unemployment rate increased by $1 \%$. This finding may well be explained by two effects. First, the annual data include shifts from unemployment to early retirement in one year. Second, in recessions, young employees became unemployed whereas older employees retired early. The other control variables do not turn out to be statistically significant in column (6).

The results in Table 1 show that leftist governments influenced neither the growth rate of revenues from contributions, nor the growth rate of revenues from tax-financed subsidies or the growth rate of pension benefits over the 1958-2007 period: the coefficient of the ideology variable in columns (1) to (6) does not turn out to be statistically significant. In a similar vein, the election year variable does not turn out to be statistically significant, indicating that politicians did not exploit social security policies to raise their chances of being returned to office.

Table 2 reports the regression results when the ideology-induced effects are measured by single coalition type dummies. None of the coalition type dummies turns out to be statistically significant in columns (1), (3), (4), and (6). The growth rate of revenues from taxfinanced subsidies, however, increased under CDU/FDP and SPD/FDP governments compared to grand coalition governments (CDU/SPD). The CDU/FDP dummy variable is 
statistically significant at the 5\% level in column (2) and at the $1 \%$ level in column (5) and indicates that the growth rate of the revenues from tax-financed subsidies increased by about 5.6 percentage points (7.6 percentage points under a CDU/FDP government) compared with a grand coalition. The SPD/FDP dummy variable is statistically significant at the 5\% level in column (5) and indicates that the growth rate of the revenues from tax-financed subsidies also increased by about 7.7 percentage points under a SPD/FDP government compared to a grand coalition. It however lacks statistical significance in column (2). The SPD/GREEN dummy variable is statistically significant at the 5\% level in column (2) but lacks statistical significance in column (5) when the control variables are included. These findings perfectly accord with the result in Table 1 that no ideology-induced effect occurred on a left-right scale. The election year variable does again not turn out to be statistically significant. The reported changes under a CDU/FDP government and a SPD/FDP government compared to a CDU/SPD government would mean, first, that tax-financed subsidies as a share of GDP increased from about $1.27 \%$ in 1983 to about $2.14 \%$ in 1998 under the CDU/FDP government. Under a CDU/SPD government the results suggest that we would have experienced decreases from about $1.27 \%$ in 1983 to about $0.74 \%$ in 1998 . Second, taxfinanced subsidies as a share of GDP increased from about $1.01 \%$ in 1970 to about $1.32 \%$ in 1982 under the SPD/FDP government. Under a CDU/SPD government the results suggest that we would have experienced decreases from about $1.01 \%$ in 1970 to about $0.48 \%$ in 1982 .

Table 3 reports the regression results for public healthcare benefits. Columns (1) and (2) refer to models when the ideology-induced effects are evaluated on the left-right scale by the variable "Left". Columns (3) and (4) refer to models when the coalition type dummies are used. ${ }^{18}$ The control variables mostly display the expected signs and again indicate wellspecified empirical models. As expected, the GDP per member of the health insurance program turns out to be a very important variable explaining healthcare benefits: its

\footnotetext{
${ }^{18}$ I employ OLS with robust standard errors in columns (1) and (3) and the Prais-Winsten-estimator in columns (2) and (4).
} 
coefficient is statistically significant at the $1 \%$ level in columns (2) and (4). The numerical meaning in column (2) (column 4) is that healthcare benefits per member increased by about $1.1 \%(0.82 \%)$ when GDP per member increased by $1 \%$. The differences in the numerical meaning may well arise from the different sample sizes (51 versus 56 observations). The mortality rate is statistically significant at the $10 \%$ level and indicates that healthcare benefits per member increased by about $0.62 \%$ when the mortality rate increased by $1 \%$. This is a reasonable finding because treatment costs dramatically increase in the last year(s) of life. The Unification Dummy turns out to be statistically significant only in column (2). The other control variables lack statistical significance. Inferences do not change when I estimate the model with OLS and robust standard errors.

The political variables do not turn out to be statistically significant in Table 3 . It is important to note that no election-motivated effects and no ideology-induced effects measured on a left-right scale are evident. Excluding control variables that lack statistical significance, however, results in statistically significant coalition type dummies. I will discuss these effects in the following.

\section{Robustness Checks}

I checked the robustness of the results in several ways. Excluding the Divided Government Dummy which lacked statistical significance in Table 3 suggest that some of the coalition type dummies become statistically significant (Table 4). This change can be explained by the correlation between the divided government dummy variable and the ideology variables: non-divided government occurred only under rightwing federal governments. Three important conclusions emerge from column (4) of Table 4. First, CDU/FDP and SPD/FDP coalitions raised somewhat the rate of growth in public healthcare benefits compared to grand coalitions. The coefficient of the CDU/FDP dummy variable is statistically significant at the $10 \%$ level and indicates that under a CDU/FDP government, the 
growth rate of healthcare benefits was by about 2.3 percentage points higher than under a grand coalition. The coefficient of the SPD/FDP dummy variable is statistically significant at the $10 \%$ level and indicates that under SPD/FDP governments, the growth rate of healthcare benefits was about 4.7 percentage points higher than under a grand coalition. This effect explains why no ideology-induced effects occurred on a left-right scale. Second, the ideologyinduced effect of the SPD/FDP coalition is somewhat larger than the ideology-induced effect of the CDU/FDP coalition (although both effects do not significantly differ statistically). This finding agrees with case study evidence that the German Social Democrats dramatically increased public health spending in the 1970s (see, for example, Schmidt 1992, 2005, 2010). Third, the SPD/FDP coalition (in power over the 1969-1982 period) pursued an expansionary healthcare policy, whereas the SPD/GREEN coalition (in power over the 1998-2005 period) pursued a much more restrictive healthcare policy (the coefficient of the SPD/GREEN dummy variable has a negative sign but lacks statistical significance at a conventional level in column (4) but is statistically significant at the 5\% level in column (3) when no control variables are included). This finding again perfectly corresponds to case study evidence (see, for example, Schmidt 2003, 2005 and Seeleib-Kaiser 2008) and helps to explain why I cannot identify an ideology-induced effect on the left-right scale: it points to a policy shift of the German Social Democrats over time. These inferences also follow from more parsimonious specifications in which I have excluded further control variables that lack statistical significance.

The leftwing SPD as well as the conservative CDU have no political economic advantages from increasing welfare expenditures when they join a coalition. If the grand coalition lasted another legislative period, both parties together would receive the majority of the votes anyhow. On the other hand, if the grand coalition collapsed, it would be difficult for voters to tell which of the parties should be punished for the collapse or which should be rewarded for increasing welfare expenditures. 
The related panel data studies for OECD countries show that government ideology influenced economic policy-making significantly during the 1970s and 1980s. In Germany a structural break occurred after the German unification in 1990. I have therefore included decadal dummy variables for the 1970-1990 period and the 1991-2007 period and interact those dummy variables with the leftwing-rightwing ideology dummy. Before interacting I have normalized (mean zero, variance one) the ideology and the decadal dummy variables. The results in Table 5 show that in the 1970-1990 period, the growth rate in revenues from contributions and tax-financed subsidies were faster under leftwing governments; so, too, were expansions in public healthcare benefits. The coefficients of the interaction terms are statistically significant at the $10 \%$ level in column (1), at the $1 \%$ level in column (2) and at the 5\% level in columns (4) and (5). By contrast, the results in Table 6 show that in the 19912007 period, the growth rates of revenues from individual contributions and tax-financed subsidies, as well as of spending on participants' healthcare benefits, were somewhat higher under rightwing governments. The coefficients of the interaction terms are statistically significant at the $10 \%$ level in columns (1) and (4) and at the $5 \%$ level in column (2). I have also calculated marginal effects at the minimum and maximum level of the interacted decadal dummy variables that support these inferences. These findings, thus, correspond to those of panel estimates both for OECD members in general and for Germany, they also explain why no ideology-induced effects on German welfare spending over the 1951-2007 period occurred.

Health care and social security appear to be political complements (Bethencourt and Galasso 2008): more health care may well increase the political constituency in favor of social security and vice-versa. For this reason, I have estimated a system of equations that considers the (potential) contemporaneous correlation between the social security indicators and public healthcare benefits (Seemingly Unrelated Regression - SUR, Zellner 1962). When contemporaneous correlation is present, the SUR estimator provides more efficient estimates 
than Ordinary Least Squares (OLS). SUR differs from OLS in my set-up because the explanatory variables differ across the specification of the social security indicators and healthcare benefits. The sample is, however, reduced to the 1957-2007 period when SUR is applied and I cannot address any serial correlation or heteroscedasticity problems as I did in Tables 1 to 4 . SUR estimates do not change the inference that government ideology did not influence the growth rate of the social security indicators and the growth rate of public healthcare benefits (results not shown).

The Unification Dummy can be coded such that it takes on the value 1 in the 19912007 period and the value 0 before 1991 (shift Unification Dummy). I have included a shift Unification Dummy which turns out positive and statistically significant in some specifications. In any event, including a shift Unification Dummy instead of an impulse Unification Dummy does not change the inferences regarding the political variables at all.

Elections need not be part of the regular electoral cycle, instead they can be irregular (early) (Shi and Svensson 2006, Brender and Drazen 2005). Following Shi and Svensson's (2006: 1374) identification strategy an election is classified as predetermined if either (i) the election is held on the fixed date (year) specified by the constitution; (ii) the election occurs in the last year of a constitutionally fixed term for the legislature; or (iii) the election is announced at least a year in advance. In Germany the 1983 and the 2005 federal elections need to be classified as early. I have replaced the election year variable by a predetermined and an early election variable. The predetermined election-year variables do not turn out to be statistically significant in either regression equation. The endogenous election-year variables turn out to be statistically significant with a negative sign in some of the social security indicator regressions. These effects point to a statistical artifact of a relatively smaller social security budget in the years 1983 and 2005 but do not indicate any further political economic meaning. 
The election year effects can be coded such that the exact timing of the elections is taken into account. Following Franzese (2000) and Mink and De Haan (2006), I have included an election year and a pre-election year variable to control directly for the fact that election dates differ across time. ${ }^{19}$ Including these variables does not change the inferences.

Globalization is believed to have ambiguous effects on the welfare state: economic reasoning either suggests that the welfare state collapses (via the supply side or efficiency effect) or that the welfare state is extended (via the demand side or compensation effect). For an encompassing portrait of the globalization-welfare state nexus see, for example, Ursprung and Schulze (1999) and Ursprung (2008). One strand of this literature deals with the structure of welfare state spending. ${ }^{20}$ Decomposing social expenditures focusing on social security and health, for example, to elucidate potential compensating effects, has enjoyed remarkable popularity in the literature. I have therefore included the growth rate of trade-openness measured by the sum of imports and exports as a share of GDP (e.g. Cameron 1978). These data are available for the entire 1951-2007 period whereas all-embracing globalization indicators such as the KOF index of globalization (Dreher 2006 and Dreher et al. 2008b) are available only from 1970. The growth rate of trade-openness does not turn out to be statistically significant and including this variable does not change the inferences. I have also interacted the growth rate of trade-openness with the left-right government ideology dummy to test whether ideology-induced social policies were restricted by preceding internationalization (Potrafke 2009a): prior internationalization did not counteract ideologyinduced social policies over the 1951-2007 period at all.

\footnotetext{
${ }^{19}$ The election year variable is calculated as Election ${ }_{t}=[(M-1)+d / D] / 12$ where $M$ is the month of the election, $d$ is the day of the election and $\mathrm{D}$ is the number of days in that month. In all other years, its values are set to zero. The Pre-Election year variable is calculated as 1 -Election $\mathrm{n}_{\mathrm{t}}$ in pre elections years and zero otherwise.

${ }^{20}$ Dreher et al. (2008a) and Gemmell et al. (2008), for example, empirically investigate the influence of globalization on budget composition.
} 


\section{Conclusion}

In Germany, leftwing and rightwing governments pursued similar social security and public healthcare policies over the 1951-2007 period. I have conducted an econometric analysis and used the available annual data on funding and benefits of the German pension and public health insurance system. Because the sample sizes (with about 50 observations) are fairly small, the regression results should be interpreted cautiously. The results correspond to case study evidence on social policies in Germany. My country study approach has the advantage that it controls for institutional characteristics. Since these characteristics are common to many other systems the inferences drawn can be transferred to other industrialized countries with similar institutions.

Electoral cohesion declined after the end of the Cold War in several industrial countries (Kittel and Obinger 2003, Potrafke 2009b, Kayser and Wlezien 2011). ${ }^{21}$ In Germany, government ideology played a significant role in economic and social policy at the federal level in the 1970s and 1980s: the leftist SPD-led governments implemented expansionary economic and social policies in the 1970s, whereas the conservative CDU/CSUled governments implemented restrictive economic and social policies in the $1980 \mathrm{~s}$. My results correspond with the related panel data and case studies that report higher social spending under leftwing governments in the 1970s and 1980s.

After German Reunification in 1990, the CDU/CSU-led governments did not persist in pursuing restrictive economic policies, but instead increased public spending and transfers to the former East Germany. Then-chancellor Helmut Kohl advocated incorporating the East Germans into the reunified German nation, although the West German social insurance system was based on a close contribution-benefit-link and the East Germans had not paid contributions in the past. In the first years after the German Unification, Helmut Kohl

\footnotetext{
${ }^{21}$ Kayser and Wlezien (2011) argue that in the course of declining electoral cohesion, voters with weak or no party affinities have strong preferences for economic voting. On economic voting in Germany see, for example, Batool and Sieg (2009).
} 
prioritized sociopolitical objectives and associated transfer payments, whereas Christian Democratic beliefs concerning a smaller role for government in the economy retired to the background (see Potrafke 2009a). Moreover, social policy was not politically controversial in the 1950s and 1960s because of citizens`craving for social peace and reconstruction after the Second World War. The lack of political controversy on social policy in the 1950s and 1960s and after 1990 explains my findings for the 1951-2007 period.

My study of Germany does not reflect an idiosyncratic German development because the fall of the Iron Curtain in 1990 had distinct consequences on economic performance and economic policy-making in most other countries all around the world. Reunification was, of course, especially important for Germany. Individual aspects of ideology-induced policy making in an unified country may or may not be a model for other now-divided nations, such as Korea.

The German case appears to be a prime example of the fact that policy convergence among established leftwing and rightwing parties opens some space at the tails of the political spectrum: in 2007, for example, the socialist party "DIE LINKE" was founded to provide socialist political platforms. One of the reasons was that the SPD had moved to the political center.

The recent demographic change and rising income inequality have contributed to healthcare policy becoming a more polarizing issue. In a similar vein, young Germans eventually will be required to finance the pensions of an aging population (economic effect of aging). Pension reforms, however, require majorities in the electorate. The number of pensioners increases and pensioners are likely to vote for reforms that foster redistribution to their own generation (political effect of aging). ${ }^{22}$ The issue of inter- and intragenerational redistribution is becoming increasingly significant in developed countries. As a consequence,

\footnotetext{
${ }^{22}$ On the political economy of social security see, for example, Breyer (1994) and Galasso and Profeta (2002). Over the period 1980-2002, industrialized democracies have not been dominated by distributive power of the elderly (Tepe and Vanhuysse 2009b). In any event, information increases support for pension reform (Boeri and Tabellini 2011).
} 
the political parties will continue to adjust their platforms and policies: will leftwing and rightwing political parties offer different policy platforms on redistribution and deductibles in the public healthcare system and on the official retirement age $?^{23}$ The first evidence revealed itself in 2010: the SPD, at this time the largest opposition party, opposed an official retirement age of 67 , although the SPD advocated an official retirement age of 67 when they formed a coalition with the CDU/CSU over the 2005-2009 period. Policy platforms on social security and public health matters are likely to undergo further changes in light of demographic change and social policy is therefore also likely to become more controversial again.

\section{Acknowledgements}

I thank Christian Bjørnskov, Viktor Brech, Friedrich Breyer, Robin Grier, Manfred G.

Schmidt, William F. Shughart II, Heinrich Ursprung, the participants of the Public Choice Society Meeting 2010 in Monterey and two anonymous referees for helpful comments and suggestions.

\footnotetext{
${ }^{23}$ Over the period 1980-2005, leftwing governments somewhat delayed social expenditure cutbacks in OECD countries (Tepe and Vanhuysse 2010).
} 


\section{References}

Aidt, T.S., Veiga, F.J., \& Veiga, L.G. (2011). Election results and opportunistic policies: A new test of the rational political business cycle. Public Choice, forthcoming.

Alber, J. (1989). Der Sozialstaat in der Bundesrepublik Deutschland 1950-1983.

Frankfurt: Campus Verlag.

Allan, J.P., \& Scruggs, L. (2004). Political partisanship and welfare state reform in advanced industrial societies. American Journal of Political Science, 48, 496-512.

Alesina, A. (1987). Macroeconomic Policy in a two-party system as a repeated game.

Quarterly Journal of Economics, 102, 651-678.

Alesina, A., Roubini, N., \& Cohen, G.D. (1997). Political cycles and the macroeconomy. Cambridge: The MIT Press.

Alesina, A., \& Rosenthal, H. (1996). A theory of divided government. Econometrica, 64, 1311-1343.

Batool, I., \& Sieg, G. (2009). Bread and the attrition of power: economic events and German election results. Public Choice, 141, 151-165.

Bawn, K. (1999). Money and majorities in the Federal Republic of Germany: Evidence from a veto players model of government spending. American Journal of Political Science, 43, 707-736.

Bechtel, M, \& Füss, R. (2010). Capitalizing on partisan politics? The political economy of sector-specific redistribution in Germany. Journal of Money, Credit and Banking, 42, 203-235.

Belke, A. (1996). Politische Konjunkturzyklen in Theorie und Empirie. Tübingen: Mohr-Siebeck Verlag.

Belke, A. (2000). Partisan political business cycles in the German labour market? Empirical tests in the light of the Lucas-critique. Public Choice, 104, 225-283.

Belke, A., Schneider, F., Baumgärtner, F., \& Setzer, R. (2007). The different extent of privatization proceeds in OECD countries: a preliminary explanation using a Public-Choice approach. FinanzArchiv/Public Finance Analysis, 63, 211-243.

Berger, H., \& Holler, A. (2007). What determines fiscal policy? CESifo Working Paper No. 2062.

Berger, H., \& Woitek, U. (1997a). Searching for political business cycles in Germany. Public Choice, 91, 179-197.

Berger, H., \& Woitek, U. (1997b). How opportunistic are German central bankers: evidence on the Vaubel hypothesis. European Journal of Political Economy, 13, 807-821. 
Berger, H., \& Woitek, U. (2001). The German political business cycle: money demand rather than monetary policy. European Journal of Political Economy, 17, 807-821.

Berger, H., \& Woitek, U. (2005). Does conservatism matter? A time-series approach to central bank behavior. Economic Journal, 115, 745-766.

Bethencourt, C., \& Galasso, V. (2008). Political complements in the welfare state: health care and social security. Journal of Public Economics, 92, 609-632.

Bjørnskov, C. (2008). The growth-inequality association: government ideology matters. Journal of Development Economics, 87, 300-308.

Blankart, C.B. (2008). Öffentliche Finanzen in der Demokratie. München: Vahlen Verlag.

Blankart, C.B. (2007). Föderalismus in Deutschland und Europa.

Baden-Baden: Nomos-Verlagsgesellschaft.

Bodea, C. (2010). The political economy of fixed exchange rate regimes: the experience of post-communist countries. European Journal of Political Economy, 26, 248-264.

Boeri, T., \& Tabellini, G. (2011). Does information increase political support for pension reform? Public Choice, forthcoming.

Brender, A., \& Drazen, A. (2005). Political budget cycles in new versus established Democracies. Journal of Monetary Economics, 52, 1271-1295.

Breyer, F. (1994). The political economy of intergenerational redistribution. European Journal of Political Economy, 10, 61-84.

Breyer, F., \& Ulrich, V. (2000). Gesundheitsausgaben, Alter und medizinischer Fortschritt: Eine Regressionsanalyse. Jahrbücher für Nationalökonomie und Statistik, 220, 1-17.

Breyer, F., Zweifel, P., \& Kifmann, M. (2009). Health Economics. 2nd edition. Berlin Heidelberg: Springer-Verlag.

Broz, J.L. (2011). The United States Congress and IMF financing, 1944-2009. Review of International Organizations, forthcoming.

Busemeyer, M.R., Goerres, A., \& Weschle, S. (2009). Attitudes towards redistributive spending in an era of demographic ageing: the rival pressures from age and income in 14 OECD countries. Journal of European Social Policy, 19, 195-212.

Cameron, D. (1978). The expansion of the public economy: a comparative analysis. American Political Science Review, 72, 1243-1261.

Congleton, R.D., \& Bose, F. (2010). The rise of the modern welfare state, ideology, Institutions and income security: analysis and evidence. Public Choice, 144, 535-555.

Congleton, R.D., \& Shughart, W.F.II (1990). The growth of social security: electoral push or political pull. Economic Inquiry, 28, 109-132. 
Cusack, T.R. (1997). Partisan politics and public finance: changes in public spending in the industrialized democracies, 1955-1989. Public Choice, 91, 375-395.

Cutler, D.M. \& Johnson, R. (2004). The birth and growth of the social insurance state: explaining old age and medical insurance across countries. Public Choice, 120, 87-121.

De Donder, P., \& Hindriks, J. (2007). Equilibrium social insurance with policy-motivated parties. European Journal of Political Economy, 23, 624-640.

De Haan, J., \& Zelhorst, D. (1993). Positive theories of public debt: Some evidence for Germany. In H. A. A Verbon, \& F. A. A. M. van Winden (Eds.), The political economy of government debt. Amsterdam: Elsevier Science Publishers B. V., 295-306.

Dreher, A. (2006). Does globalization affect growth? Evidence from a new index of globalization. Applied Economics, 38, 1091-1110.

Dreher, A., Sturm, J.-E., \& Ursprung, H.W. (2008a). The impact of globalization on the composition of government expenditures: Evidence from panel data. Public Choice, 134, 263-292.

Dreher, A., Gaston N., \& Martens, P. (2008b). Measuring globalization - Gauging its consequences. Berlin: Springer.

Franzese, R. (2000). Electoral and partisan manipulation of public debt in developed democracies, 1956-1990. In R. Strauch, \& J. von Hagen (Eds.), Institutions, politics and fiscal policy. Dordrecht: Kluwer Academic Press, 61-83.

Füss, R., \& Bechtel, M. (2008). Partisan politics and stock market performance: the effect of expected government partisanship on stock returns in the 2002 federal German election. Public Choice, 135, 131-150.

Galasso, V., \& Profeta, P. (2002). The political economy of social security: a survey. European Journal of Political Economy, 18, 1-29.

Galli, E., \& Rossi, S. (2002). Political budget cycles: The case of the Western German Länder. Public Choice, 110, 283-303.

Gemmell, N., Kneller, R., \& Sanz, I. (2008). Foreign investment, international trade and the size and structure of public expenditures.

European Journal of Political Economy, 24, 151-171.

Goehlmann, S., \& Vaubel, R. (2007). The educational and occupational background of central bankers and its effect on inflation: an empirical analysis.

European Economic Review, 51, 925-941. 
Grier, K. (2008). US presidential elections and real GDP growth, 1961-2004.

Public Choice, 135, 337-352.

Hibbs, D.A.Jr. (1977). Political parties and macroeconomic policy.

American Political Science Review, 71, 1467-1487.

Hicks, A.M., \& Swank, D.H. (1992). Politics, institutions, and welfare spending in industrialized democracies, 1960-1982.

American Political Science Review, 86, 658-674.

Huber, E., \& Stephens, J.D. (2001). Development and crisis of the welfare state. Parties And policies in global markets. Chicago and London: University of Chicago Press.

Immergut, E.M. (1992). Health politics - Interests and institutions in Western Europe. Cambridge: Cambridge University Press.

Iversen, T. \& Soskice, D. (2001). An asset theory of social policy preferences. American Political Science Review, 95, 875-893.

Jensen, C. (2011a). Marketization via compensation: health care and the politics of the right In advanced industrialized nations. British Journal of Political Science, forthcoming.

Jensen, C. (2011b). Determinants of welfare service provision after the Golden Age. International Journal of Social Welfare, forthcoming.

Kayser, M.A., \& Wlezien, C. (2011). Performance pressure: patterns of partisanship and the economic vote. European Journal of Political Research, 50, 365-394.

Kemmerling, A., \& Neugart, M. (2009). Financial market lobbies and pension reform. European Journal of Political Economy, 25, 163-173.

Kittel, B., \& Obinger, H. (2003). Politicial parties, institutions, and the dynamics of social expenditure in times of austerity. Journal of European Public Policy, 10, 20-45.

Koester, G.B. (2009). The political economy of tax reforms - an empirical analysis of new German data. Baden-Baden: Nomos-Verlagsgesellschaft.

Korpi, W., \& Palme, J. (2003). New politics and class politics in the context of austerity and globalization: welfare state regress in 18 countries, 1975-95.

American Political Science Review, 97, 425-446.

König, T., \& Tröger, V. (2005). Budgetary politics and veto players.

Swiss Political Science Review, 11, 47-75.

Lanne, M., Lütkepohl, H., \& Saikkonen, P. (2002). Comparison of unit root tests for time series with a level shifts. Journal of Time Series, 23, 667-685.

Le Maux, B., Rocaboy, Y., \& Goodspeed, T. (2011). Political fragmentation, party ideology and public expenditures. Public Choice, 147, 43-67. 
Leunig, S., \& Bauer, T. (2006). Die Entwicklung der parteipolitischen Mehrheitsverhältnisse in Bundestag und Bundesrat seit 1949. URL: http://www.foederalismus.uni-jena.de/foederalismus/

Lohmann, S. (1998). Federalism and central bank independence: the politics of German monetary policies, 1957-92. World Politics, 50, 401-446

Mink, M., \& De Haan, J. (2006). Are there political budget cycles in the euro area? European Union Politics, 7, 191-211.

Moene, K.O., \& Wallerstein, M. (2001). Inequality, social insurance, and redistribution. American Political Science Review, 95, 859-874.

Nordhaus, W.D. (1975). The political business cycle. Review of Economic Studies, 42, 169-190.

Oberndorfer, U., \& Steiner, V. (2007). Generationen- oder Parteienkonflikt? Eine empirische Analyse der deutschen Hochschulausgaben.

Perspektiven der Wirtschaftspolitik, 8, 165-183.

Perron, P. (1989). The great clash, the oil price shock, and the unit root hypothesis. Econometrica, 57, 1361-1401.

Perron, P. (1990). Testing for a unit root in a time series with a changing mean. Journal of Business \& Economic Statistics, 8, 153-162.

Pierson, P. (1996). The new politics of the welfare state. World Politics, 48, 143-179.

Pierson, P. (2001). Post-industrial pressures on the mature welfare states. In Pierson, P. (Eds.), The new politics of the welfare state. Oxford: Oxford University Press, 80-104.

Potrafke, N. (2009a). Did globalization restrict partisan politics? An empirical evaluation of social expenditures in a panel of OECD countries. Public Choice, 140, 105-124.

Potrafke, N. (2009b). Konvergenz in der deutschen Finanz- und Sozialpolitik? Hamburg/Münster: LIT.

Potrafke, N. (2010). The growth of public health expenditures in OECD countries: do government ideology and electoral motives matter? Journal of Health Economics, 29, 797-810.

Potrafke, N. (2011). Public expenditures on education and cultural affairs in the West German states: does government ideology influence the budget composition? German Economic Review, 12, 124-145.

Rogoff, K. (1990). Equilibrium political budget cycles. American Economic Review, 80, 21-36. 
Rogoff, K., \& Sibert, A. (1988). Elections and macroeconomic policy cycles. Review of Economic Studies, 55, 1-16.

Saikkonen, P., \& Lütkepohl, H. (2002). Testing for a unit root in a time series with a level shift at unknown time. Econometric Theory, 18, 313-348.

Sakamoto, T. (2008). Economic policy and performance in industrial democracies - party governments, central banks and the fiscal-monetary policy mix. London/New York: Routledge.

Schmidt, M.G. (1992). Regieren in der Bundesrepublik Deutschland. Opladen: Leske + Budrich.

Schmidt, M.G. (2002). The impact of political parties, constitutional structures and veto players on public policy. In H. Keman (Eds.), Comparative democratic politics. London: SAGE, 166-184.

Schmidt, M.G. (2003). Rot-grüne Sozialpolitik. In C. Egle, T. Ostheim, \& R. Zohlnhöfer (Eds.), Das rot-grüne Projekt - Eine Bilanz der Regierung Schröder 1998-2002. Wiesbaden,/Tübingen: Westdeutscher Verlag, 239-258.

Schmidt, M.G. (2005). Sozialpolitik in Deutschland. 3rd edition, Wiesbaden: VS Verlag für Sozialwissenschaften.

Schmidt, M.G. (2010). Parties. In F.G Castles, S. Leibfried, J. Lewis, H. Obinger, C. Pierson (Eds.), Oxford Handbook on the welfare state: Oxford University Press, 211-226.

Schmähl, W. (1993). The '1992 Reform'of public pensions in Germany: main elements and some effects. Journal of European Social Policy, 3, 39-51.

Schneider, C.J. (2010). Fighting with one hand tied behind the back: political budget cycles in the German states. Public Choice, 142, 125-150.

Schulze, G.G., \& Ursprung, H.W. (1999). Globalisation of the economy and the nation state. World Economy, 22, 295-352.

Seeleib-Kaiser, M. (2008). Reframing social policy: From conservatism to liberal communitarism. German Policy Studies, 4, 67-100.

Seeleib-Kaiser, M., Van Dyk, S., \& Roggenkamp, M. (2008). Polity Politics and Social Welfare: Comparing Christian and Social Democracy in Austria, Germany and the Netherlands. In D. Bouget, J. Lewis, \& G. Bonoli: Globalisation and Welfare Series. Cheltenham: Edward Elgar.

Shi, M., \& Svensson, J. (2006). Political budget cycles: Do they differ across countries and why? Journal of Public Economics, 90, 1367-1389. 
Seitz, H. (2000). Fiscal policy, deficits and politics of subnational governments: The case of The German Laender. Public Choice, 102, 183-218.

Seitz, H. (2008). Die Bundesbestimmtheit der Länderausgaben. Wirtschaftsdienst, 88, 340-348.

Tepe, M. \& Vanhuysse, P. (2009a). Educational business cycles - The political economy of teacher hiring across German states, 1992-2004. Public Choice, 139, 61-82.

Tepe, M. \& Vanhuysse, P. (2009b). Are aging OECD welfare states on the path to gerontocracy? Evidence from 18 democracies, 1980-2002.

Journal of Public Policy, 29, 1-28.

Tepe, M. \& Vanhuysse, P. (2010). Who cuts back and when? The politics of delays in social expenditure cutbacks, 19850-2005. West European Politics, 33, 1214-1240.

Ursprung, H.W. (2008). Globalisation and the welfare state. In S. N. Durlauf, \& L. E.Blume (Eds.), The New Palgrave Dictionary of Economics, Second edition. Köln: Palgrave Macmillan.

Van Kersbergen, K. (1995). Social capitalism. A study of christian democracy and the Welfare state. London: Routledge.

Vaubel, R. (1993). Eine Public-Choice-Analyse der Deutschen Bundesbank und ihre Implikationen für die Europäische Währungsunion. In D. Duwendag, \& J. Siebke (Eds.), Europa vor dem Eintritt in die Wirtschafts- und Währungsunion, Berlin: Duncker und Humblot, 23-79.

Vaubel, R. (1997a). The bureaucratic and partisan behaviour of independent central banks: German and international evidence.

European Journal of Political Economy, 13, 201-224.

Vaubel, R. (1997b). Reply to Berger and Woitek.

European Journal of Political Economy, 13, 823-827.

Vaubel, R. (1999). Comment on Susanne Lohmann. University of Mannheim. http://www.vwl.unimannheim.de/vaubel/pdfDateien/Comment_on_Susanne_Lohmann.pdf

Zellner, A. (1962). An efficient method of estimating seemingly unrelated regressions and tests of aggregation bias. Journal of the American Statistical Association, 57, 348-368. 
Figure 1: Revenues from Contributions, Tax-financed subsidies and expenditures for Pension benefits of the German Pension Insurance in the 1957-2007 period (as a share of GDP).

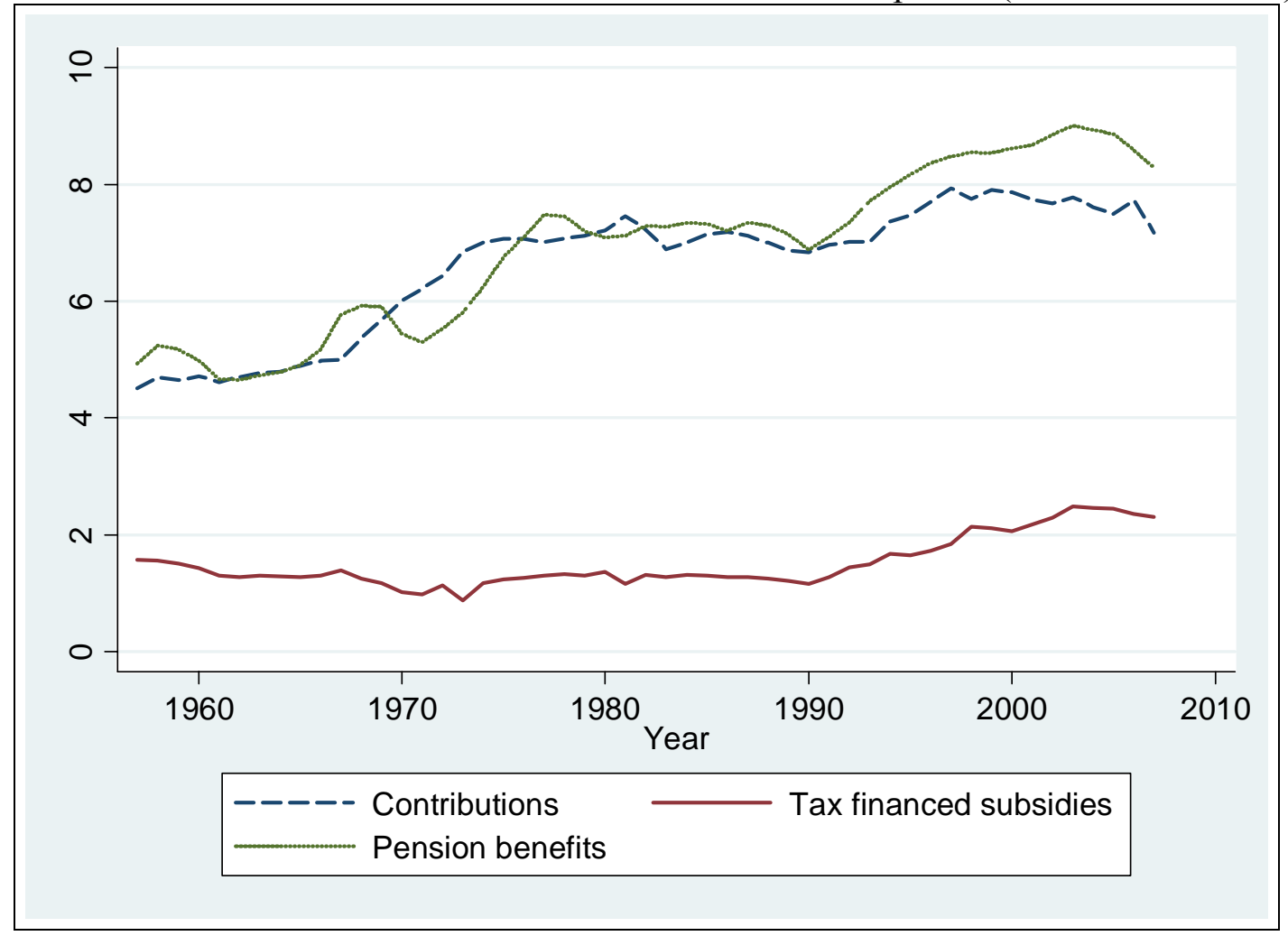

Source: German Pension Insurance and German Federal Statistical Office

Figure 2: Expenditures for public healthcare benefits of the German Public Health Insurance in the 1951-2007 period

(per member of the German Public Health Insurance, Euros, constant prices).

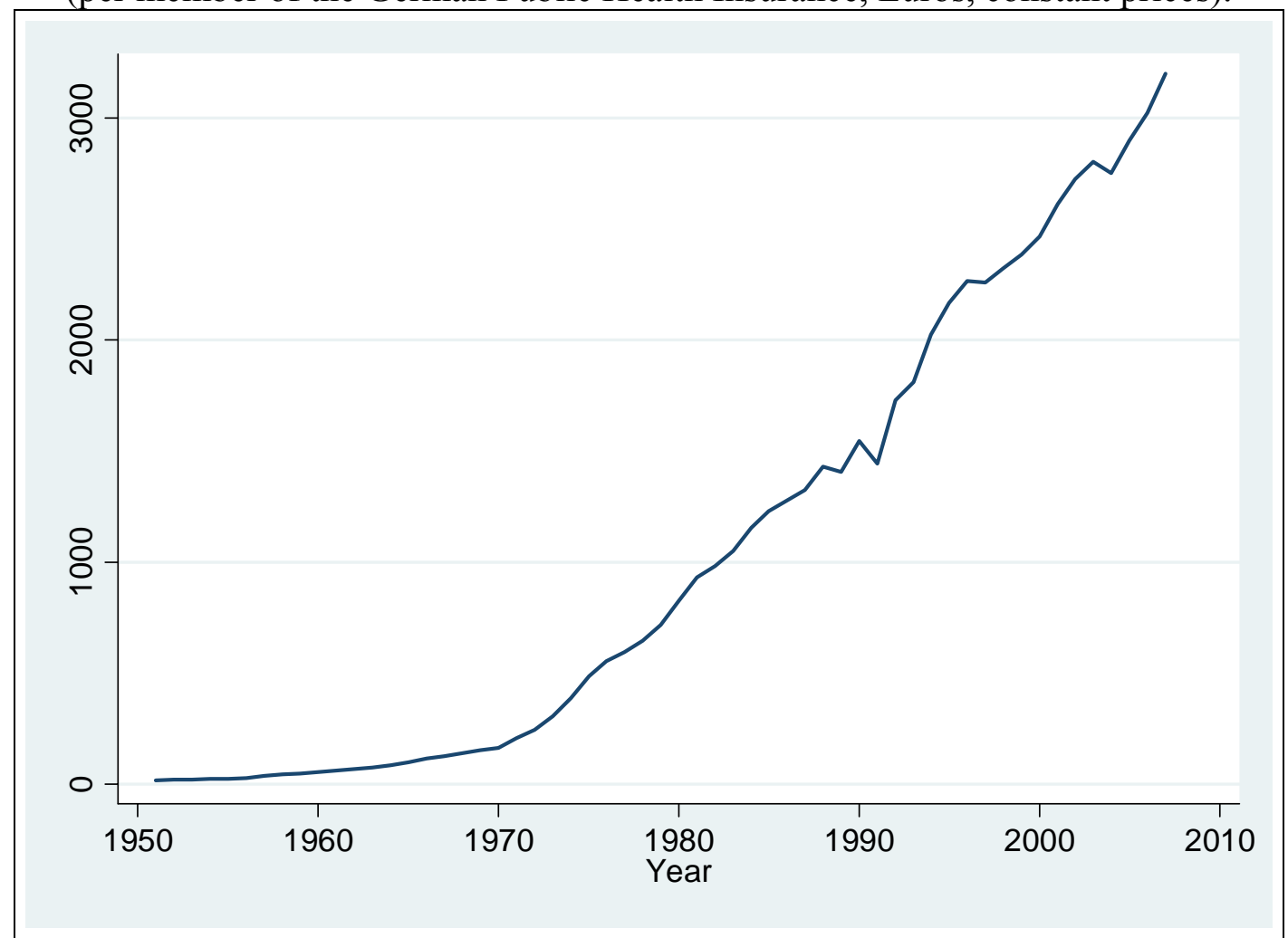

Source: German Federal Ministry of Public Health and German Federal Statistical Office 
Table 1: Regression Results. Prais Winsten estimator with robust standard errors.

Leftist government.

Dependent variable: growth rate of the Revenues from Contributions, Tax-financed subsidies and expenditures for Pension benefits of the German Pension Insurance in the 1957-2007 period (as a share of GDP).

\begin{tabular}{|c|c|c|c|c|c|c|}
\hline & $\begin{array}{c}(1) \\
\Delta \ln \\
\text { contributions }\end{array}$ & $\begin{array}{c}(2) \\
\Delta \ln \\
\text { Tax-financed } \\
\text { subsidies }\end{array}$ & $\begin{array}{c}(3) \\
\Delta \ln \\
\text { pension } \\
\text { benefits }\end{array}$ & $\begin{array}{c}(4) \\
\Delta \ln \\
\text { contributions }\end{array}$ & $\begin{array}{c}(5) \\
\Delta \ln \\
\text { Tax-financed } \\
\text { subsidies }\end{array}$ & $\begin{array}{c}(6) \\
\Delta \ln \\
\text { pension } \\
\text { benefits }\end{array}$ \\
\hline Election & $\begin{array}{c}-0.0116 \\
{[1.66]}\end{array}$ & $\begin{array}{l}0.0137 \\
{[0.47]}\end{array}$ & $\begin{array}{c}-0.0061 \\
{[0.87]}\end{array}$ & $\begin{array}{c}-0.0116 \\
{[1.49]}\end{array}$ & $\begin{array}{l}0.0218 \\
{[0.94]}\end{array}$ & $\begin{array}{c}-0.0005 \\
{[0.07]}\end{array}$ \\
\hline Left & $\begin{array}{l}0.0043 \\
{[0.49]}\end{array}$ & $\begin{array}{c}0.003 \\
{[0.14]}\end{array}$ & $\begin{array}{c}-0.0033 \\
{[0.21]}\end{array}$ & $\begin{array}{c}-0.0068 \\
{[0.82]}\end{array}$ & $\begin{array}{c}-0.0175 \\
{[1.06]}\end{array}$ & $\begin{array}{c}-0.0096 \\
{[0.87]}\end{array}$ \\
\hline$\Delta \ln$ Unemployment & & & & $\begin{array}{l}0.0040 \\
{[0.24]}\end{array}$ & $\begin{array}{c}0.2017 * * * \\
{[4.82]}\end{array}$ & $\begin{array}{c}0.1030 * * * \\
{[4.23]}\end{array}$ \\
\hline$\Delta \ln$ Compensation of Employees & & & & $\begin{array}{c}0.2939 * \\
{[2.03]}\end{array}$ & $\begin{array}{c}-0.4881 \\
{[1.21]}\end{array}$ & $\begin{array}{c}-0.1176 \\
{[0.48]}\end{array}$ \\
\hline$\Delta \ln$ Dependency ratio & & & & $\begin{array}{l}0.3259 \\
{[1.35]}\end{array}$ & $\begin{array}{c}0.8863^{*} \\
{[2.02]}\end{array}$ & $\begin{array}{c}0.3804 \\
{[1.59]}\end{array}$ \\
\hline Linear time trend & & & & $\begin{array}{l}0.0003 \\
{[0.54]}\end{array}$ & $\begin{array}{c}-0.0003 \\
{[0.29]}\end{array}$ & $\begin{array}{c}-0.0005 \\
{[0.78]}\end{array}$ \\
\hline Unification Dummy & & & & $\begin{array}{c}0.0275 * * * \\
{[2.92]}\end{array}$ & $\begin{array}{c}0.1019 * \\
{[1.77]}\end{array}$ & $\begin{array}{l}0.0278 \\
{[1.56]}\end{array}$ \\
\hline Constant & $\begin{array}{c}0.0101 * \\
{[1.90]} \\
\end{array}$ & $\begin{array}{c}0.0082 \\
{[0.74]} \\
\end{array}$ & $\begin{array}{c}0.0128 \\
{[1.18]} \\
\end{array}$ & $\begin{array}{c}-0.0210 \\
{[0.84]} \\
\end{array}$ & $\begin{array}{l}0.0460 \\
{[0.81]} \\
\end{array}$ & $\begin{array}{l}0.0342 \\
{[0.89]} \\
\end{array}$ \\
\hline Observations & 45 & 45 & 45 & 45 & 45 & 45 \\
\hline R-squared & 0.09 & 0.01 & 0.01 & 0.30 & 0.51 & 0.45 \\
\hline DW-statistic (transformed) & 1.90 & 1.90 & 1.45 & 1.88 & 2.00 & 1.66 \\
\hline DW-statistic (original) & 1.36 & 2.48 & 0.73 & 1.84 & 2.89 & 1.26 \\
\hline
\end{tabular}

Notes: Absolute value of $t$ statistics in brackets; $*$ significant at $10 \% ; * *$ significant at $5 \% ; * * *$ significant at $1 \%$ 
Table 2: Regression Results. Prais Winsten estimator with robust standard errors.

Coalition dummies.

Dependent variable: growth rate of the Revenues from Contributions, Tax-financed subsidies and expenditures for Pension benefits of the German Pension Insurance in the 1957-2007 period (as a share of GDP).

\begin{tabular}{|c|c|c|c|c|c|c|}
\hline & $\begin{array}{c}(1) \\
\Delta \ln \\
\text { Contributions }\end{array}$ & $\begin{array}{c}(2) \\
\Delta \ln \\
\text { Tax-financed } \\
\text { subsidies }\end{array}$ & $\begin{array}{c}(3) \\
\Delta \ln \\
\text { Pension } \\
\text { benefits }\end{array}$ & $\begin{array}{c}(4) \\
\Delta \ln \\
\text { Contributions }\end{array}$ & $\begin{array}{c}(5) \\
\Delta \ln \\
\text { Tax-financed } \\
\text { subsidies }\end{array}$ & $\begin{array}{c}(6) \\
\Delta \ln \\
\text { Pension } \\
\text { benefits }\end{array}$ \\
\hline Election & $\begin{array}{c}-0.0086 \\
{[1.17]}\end{array}$ & $\begin{array}{l}0.0006 \\
{[0.02]}\end{array}$ & $\begin{array}{c}-0.0025 \\
{[0.34]}\end{array}$ & $\begin{array}{c}-0.0078 \\
{[0.92]}\end{array}$ & $\begin{array}{l}0.0205 \\
{[0.91]}\end{array}$ & $\begin{array}{c}0.0008 \\
{[0.12]}\end{array}$ \\
\hline CDU/FDP & $\begin{array}{c}-0.0063 \\
{[0.24]}\end{array}$ & $\begin{array}{c}0.0555^{* *} \\
{[2.41]}\end{array}$ & $\begin{array}{c}-0.0244 \\
{[0.74]}\end{array}$ & $\begin{array}{c}-0.0076 \\
{[0.30]}\end{array}$ & $\begin{array}{c}0.0758 * * * \\
{[3.46]}\end{array}$ & $\begin{array}{c}-0.0108 \\
{[0.60]}\end{array}$ \\
\hline SPD/FDP & $\begin{array}{c}0.0046 \\
{[0.17]}\end{array}$ & $\begin{array}{l}0.0516 \\
{[1.50]}\end{array}$ & $\begin{array}{c}-0.0245 \\
{[0.59]}\end{array}$ & $\begin{array}{l}-0.004 \\
{[0.15]}\end{array}$ & $\begin{array}{c}0.0765^{* *} \\
{[2.63]}\end{array}$ & $\begin{array}{l}-0.028 \\
{[0.79]}\end{array}$ \\
\hline SPD/GREEN & $\begin{array}{c}-0.0168 \\
{[0.65]}\end{array}$ & $\begin{array}{c}0.0671 * * \\
{[2.62]}\end{array}$ & $\begin{array}{c}-0.0147 \\
{[0.43]}\end{array}$ & $\begin{array}{c}-0.0136 \\
{[0.45]}\end{array}$ & $\begin{array}{l}0.0292 \\
{[1.22]}\end{array}$ & $\begin{array}{c}0.0024 \\
{[0.15]}\end{array}$ \\
\hline$\Delta \ln$ Unemployment & & & & $\begin{array}{c}-0.0094 \\
{[0.67]}\end{array}$ & $\begin{array}{c}0.1424 * * * \\
{[4.96]}\end{array}$ & $\begin{array}{c}0.0695 * * * \\
{[5.67]}\end{array}$ \\
\hline$\Delta \ln$ Compensation of Employees & & & & $\begin{array}{l}0.1751 \\
{[1.11]}\end{array}$ & $\begin{array}{c}-0.4084 \\
{[1.01]}\end{array}$ & $\begin{array}{c}-0.0035 \\
{[0.02]}\end{array}$ \\
\hline$\Delta \ln$ Dependency ratio & & & & $\begin{array}{c}0.3544 \\
{[1.05]}\end{array}$ & $\begin{array}{c}1.0308 * * \\
{[2.05]}\end{array}$ & $\begin{array}{c}-0.0932 \\
{[0.20]}\end{array}$ \\
\hline Linear time trend & & & & $\begin{array}{c}-0.0002 \\
{[0.36]}\end{array}$ & $\begin{array}{l}0.0007 \\
{[1.01]}\end{array}$ & $\begin{array}{c}-0.0009 \\
{[1.40]}\end{array}$ \\
\hline Unification Dummy & & & & $\begin{array}{c}0.0286^{* * *} \\
{[2.79]}\end{array}$ & $\begin{array}{l}0.0975 \\
{[1.65]}\end{array}$ & $\begin{array}{l}0.0313 \\
{[1.34]}\end{array}$ \\
\hline Constant & $\begin{array}{c}0.0156 \\
{[0.60]} \\
\end{array}$ & $\begin{array}{c}-0.0430 * \\
{[1.97]} \\
\end{array}$ & $\begin{array}{c}0.0312 \\
{[0.98]} \\
\end{array}$ & $\begin{array}{l}0.0074 \\
{[0.26]} \\
\end{array}$ & $\begin{array}{c}-0.0711 \\
{[1.43]} \\
\end{array}$ & $\begin{array}{l}0.0522 \\
{[1.29]}\end{array}$ \\
\hline Observations & 50 & 50 & 50 & 50 & 50 & 50 \\
\hline R-squared & 0.07 & 0.06 & 0.04 & 0.22 & 0.56 & 0.46 \\
\hline DW-statistic (transformed) & 1.73 & 1.96 & 1.58 & 1.73 & 2.18 & 1.82 \\
\hline DW-statistic (original) & 1.42 & 2.51 & 0.89 & 1.60 & 2.99 & 1.45 \\
\hline
\end{tabular}

Notes: Absolute value of $t$ statistics in brackets; * significant at 10\%; ** significant at 5\%; *** significant at $1 \%$ 
Table 3: Regression Results. Prais Winsten estimator with robust standard errors.

Dependent variable: growth rate of the expenditures for public healthcare benefits of the German Public Health Insurance in the 1951-2007 period

(per member of the German Public Health Insurance, Euros, constant prices).

\begin{tabular}{|c|c|c|c|c|}
\hline & (1) & (2) & (3) & (4) \\
\hline Election & $\begin{array}{c}0.0206 \\
{[1.33]}\end{array}$ & $\begin{array}{c}0.0155 \\
{[1.12]}\end{array}$ & $\begin{array}{c}0.0233 \\
{[1.48]}\end{array}$ & $\begin{array}{c}0.0162 \\
{[1.26]}\end{array}$ \\
\hline Left & $\begin{array}{c}0.0035 \\
{[0.11]}\end{array}$ & $\begin{array}{c}-0.0023 \\
{[0.11]}\end{array}$ & & \\
\hline CDU/FDP & & & $\begin{array}{c}0.0136 \\
{[0.61]}\end{array}$ & $\begin{array}{l}0.0199 \\
{[1.34]}\end{array}$ \\
\hline $\mathrm{SPD} / \mathrm{FDP}$ & & & $\begin{array}{l}0.0597 \\
{[1.51]}\end{array}$ & $\begin{array}{c}0.0402 \\
{[1.30]}\end{array}$ \\
\hline SPD/GREEN & & & $\begin{array}{c}-0.0416 \\
{[1.35]}\end{array}$ & $\begin{array}{c}-0.0242 \\
{[1.04]}\end{array}$ \\
\hline Divided Government & $\begin{array}{c}0.0098 \\
{[0.33]}\end{array}$ & $\begin{array}{l}0.0063 \\
{[0.33]}\end{array}$ & $\begin{array}{c}0.0047 \\
{[0.17]}\end{array}$ & $\begin{array}{c}0.0066 \\
{[0.35]}\end{array}$ \\
\hline$\Delta \ln$ GDP per member & & $\begin{array}{c}1.1171 * * * \\
{[3.87]}\end{array}$ & & $\begin{array}{c}0.8235^{* * *} * \\
{[2.98]}\end{array}$ \\
\hline$\Delta \ln$ Dependency ratio & & $\begin{array}{c}0.4027 \\
{[0.88]}\end{array}$ & & $\begin{array}{c}0.8715 \\
{[1.67]}\end{array}$ \\
\hline$\Delta \ln$ Mortality rate & & $\begin{array}{c}0.6130^{*} \\
{[1.75]}\end{array}$ & & $\begin{array}{c}0.6259 * \\
{[1.99]}\end{array}$ \\
\hline$\Delta \ln$ Linear time trend & & $\begin{array}{l}0.046 \\
{[0.59]}\end{array}$ & & $\begin{array}{c}0.0408 \\
{[0.55]}\end{array}$ \\
\hline Unification Dummy & & $\begin{array}{c}0.1268 * \\
{[1.71]}\end{array}$ & & $\begin{array}{c}0.0668 \\
{[1.01]}\end{array}$ \\
\hline Constant & $\begin{array}{c}0.0815^{* * *} \\
{[3.87]}\end{array}$ & $\begin{array}{c}-0.0068 \\
{[0.26]}\end{array}$ & $\begin{array}{c}0.0682 * * * \\
{[4.54]}\end{array}$ & $\begin{array}{c}-0.0088 \\
{[0.35]}\end{array}$ \\
\hline Observations & 51 & 51 & 56 & 56 \\
\hline R-squared & 0.05 & 0.51 & 0.18 & 0.56 \\
\hline DW-statistic (transformed) & 2.25 & 1.74 & 2.11 & 1.99 \\
\hline DW-statistic (original) & 1.06 & 1.63 & 1.51 & 1.91 \\
\hline
\end{tabular}


Table 4: Regression Results. Prais Winsten estimator with robust standard errors.

Coalition dummies.

Dependent variable: growth rate of the expenditures for public healthcare benefits of the German Public Health Insurance in the 1951-2007 period

(per member of the German Public Health Insurance, Euros, constant prices).

Without Divided Government Dummy Variable.

\begin{tabular}{|c|c|c|c|c|}
\hline & (1) & (2) & (3) & (4) \\
\hline$\overline{\text { Election }}$ & $\begin{array}{l}0.0212 \\
{[1.40]}\end{array}$ & $\begin{array}{l}0.016 \\
{[1.14]}\end{array}$ & $\begin{array}{l}0.0236 \\
{[1.51]}\end{array}$ & $\begin{array}{l}0.0167 \\
{[1.28]}\end{array}$ \\
\hline Left & $\begin{array}{l}0.0077 \\
{[0.29]}\end{array}$ & $\begin{array}{l}0.0009 \\
{[0.06]}\end{array}$ & & \\
\hline CDU/FDP & & & $\begin{array}{l}0.0162 \\
{[0.80]}\end{array}$ & $\begin{array}{c}0.0230^{*} \\
{[1.72]}\end{array}$ \\
\hline SPD/FDP & & & $\begin{array}{c}0.0643^{* *} \\
{[2.21]}\end{array}$ & $\begin{array}{c}0.0467^{*} \\
{[1.94]}\end{array}$ \\
\hline SPD/GREEN & & & $\begin{array}{c}-0.0372 * * \\
{[2.08]}\end{array}$ & $\begin{array}{c}-0.0176 \\
{[1.42]}\end{array}$ \\
\hline$\Delta \ln$ GDP per member & & $\begin{array}{c}1.1145^{* * *} \\
{[3.91]}\end{array}$ & & $\begin{array}{c}0.8216^{* * *} \\
{[3.02]}\end{array}$ \\
\hline$\Delta \ln$ Dependency ratio & & $\begin{array}{c}0.4044 \\
{[0.88]}\end{array}$ & & $\begin{array}{l}0.8713 \\
{[1.67]}\end{array}$ \\
\hline$\Delta \ln$ Mortality rate & & $\begin{array}{c}0.6047^{*} \\
{[1.74]}\end{array}$ & & $\begin{array}{c}0.6174^{*} \\
{[1.97]}\end{array}$ \\
\hline$\Delta \ln$ Linear time trend & & $\begin{array}{l}0.0586 \\
{[0.78]}\end{array}$ & & $\begin{array}{l}0.0542 \\
{[0.80]}\end{array}$ \\
\hline Unification Dummy & & $\begin{array}{c}0.1289^{*} \\
{[1.76]}\end{array}$ & & $\begin{array}{l}0.0692 \\
{[1.06]}\end{array}$ \\
\hline Constant & $\begin{array}{c}0.0871 * * * \\
{[4.18]}\end{array}$ & $\begin{array}{l}-0.004 \\
{[0.17]}\end{array}$ & $\begin{array}{c}0.0683 * * * \\
{[4.60]}\end{array}$ & $\begin{array}{c}-0.0091 \\
{[0.36]}\end{array}$ \\
\hline Observations & 51 & 51 & 56 & 56 \\
\hline R-squared & 0.04 & 0.51 & 0.17 & 0.56 \\
\hline DW-statistic (transformed) & 2.25 & 1.74 & 2.12 & 1.99 \\
\hline DW-statistic (original) & 1.06 & 1.63 & 1.50 & 1.90 \\
\hline
\end{tabular}


Table 5: Regression Results. Prais Winsten estimator with robust standard errors.

\section{Leftist government.}

\section{Interaction with 1970-1990 decadal dummy.}

Dependent variable: growth rate of the Revenues from Contributions, Tax-financed subsidies and expenditures for Pension benefits of the German Pension Insurance (as a share of GDP) 1957-2007 and expenditures for public healthcare benefits of the German Public Health Insurance (per member of the German Public Health Insurance, Euros, constant prices) 19512007.

\begin{tabular}{|c|c|c|c|c|c|}
\hline & $\begin{array}{c}(1) \\
\Delta \ln \\
\text { Contributions }\end{array}$ & $\begin{array}{c}(2) \\
\Delta \ln \\
\text { Tax-financed } \\
\text { subsidies } \\
\end{array}$ & $\begin{array}{c}(3) \\
\Delta \ln \\
\text { Pension } \\
\text { benefits }\end{array}$ & $\begin{array}{c}(4) \\
\Delta \ln \\
\text { Healthcare } \\
\text { benefits }\end{array}$ & $\begin{array}{c}(5) \\
\Delta \ln \\
\text { Healthcare } \\
\text { benefits }\end{array}$ \\
\hline Election & $\begin{array}{c}-0.0109 \\
{[1.05]}\end{array}$ & $\begin{array}{c}0.0296 \\
{[1.00]}\end{array}$ & $\begin{array}{l}0.0005 \\
{[0.05]}\end{array}$ & $\begin{array}{c}0.0226 \\
{[1.17]}\end{array}$ & $\begin{array}{c}0.0218 \\
{[1.16]}\end{array}$ \\
\hline Left & $\begin{array}{l}-0.005 \\
{[1.13]}\end{array}$ & $\begin{array}{c}-0.0064 \\
{[0.74]}\end{array}$ & $\begin{array}{l}-0.002 \\
{[0.45]}\end{array}$ & $\begin{array}{c}-0.0046 \\
{[0.51]}\end{array}$ & $\begin{array}{c}-0.0058 \\
{[0.94]}\end{array}$ \\
\hline Dummy 1970-1990 & $\begin{array}{l}0.004 \\
{[0.78]}\end{array}$ & $\begin{array}{c}-0.0033 \\
{[0.38]}\end{array}$ & $\begin{array}{c}-0.0084 \\
{[0.97]}\end{array}$ & $\begin{array}{l}0.006 \\
{[0.50]}\end{array}$ & $\begin{array}{l}0.0069 \\
{[0.66]}\end{array}$ \\
\hline Left* Dummy 1970-1990 & $\begin{array}{c}0.0098 * \\
{[1.75]}\end{array}$ & $\begin{array}{c}0.0243 * * * \\
{[2.74]}\end{array}$ & $\begin{array}{l}0.0073 \\
{[1.17]}\end{array}$ & $\begin{array}{c}0.0194^{* *} \\
{[2.19]}\end{array}$ & $\begin{array}{c}0.0188^{* *} \\
{[2.17]}\end{array}$ \\
\hline$\Delta \ln$ Unemployment & $\begin{array}{l}0.0007 \\
{[0.04]}\end{array}$ & $\begin{array}{c}0.1995 * * * \\
{[4.91]}\end{array}$ & $\begin{array}{c}0.1006 * * * \\
{[4.09]}\end{array}$ & & \\
\hline$\Delta \ln$ Compensation of Employees & $\begin{array}{l}0.1761 \\
{[1.09]}\end{array}$ & $\begin{array}{c}-0.8078^{* *} \\
{[2.05]}\end{array}$ & $\begin{array}{c}-0.1427 \\
{[0.57]}\end{array}$ & & \\
\hline$\Delta \ln$ Dependency ratio & $\begin{array}{l}0.4854 \\
{[1.50]}\end{array}$ & $\begin{array}{l}0.7461 \\
{[1.13]}\end{array}$ & $\begin{array}{c}0.1466 \\
{[0.41]}\end{array}$ & $\begin{array}{l}0.6487 \\
{[0.97]}\end{array}$ & $\begin{array}{c}0.6759 \\
{[1.11]}\end{array}$ \\
\hline Linear time trend & $\begin{array}{l}0.0005 \\
{[0.92]}\end{array}$ & $\begin{array}{c}-0.0001 \\
{[0.13]}\end{array}$ & $\begin{array}{c}-0.0004 \\
{[0.62]}\end{array}$ & & \\
\hline Divided Government & & & & $\begin{array}{c}-0.0039 \\
{[0.18]}\end{array}$ & \\
\hline$\Delta \ln$ GDP per member & & & & $\begin{array}{c}0.8067 * * \\
{[2.62]}\end{array}$ & $\begin{array}{c}0.8096^{* *} \\
{[2.69]}\end{array}$ \\
\hline$\Delta \ln$ Mortality rate & & & & $\begin{array}{c}0.5868 \\
{[1.64]}\end{array}$ & $\begin{array}{c}0.5934^{*} \\
{[1.69]}\end{array}$ \\
\hline$\Delta \ln$ Linear time trend & & & & $\begin{array}{c}0.0361 \\
{[0.49]}\end{array}$ & $\begin{array}{l}0.032 \\
{[0.48]}\end{array}$ \\
\hline Unification Dummy & $\begin{array}{c}0.0196 \\
{[1.62]}\end{array}$ & $\begin{array}{l}0.0715 \\
{[1.28]}\end{array}$ & $\begin{array}{c}0.0095 \\
{[0.46]}\end{array}$ & $\begin{array}{c}0.0552 \\
{[0.68]}\end{array}$ & $\begin{array}{c}0.0558 \\
{[0.70]}\end{array}$ \\
\hline Constant & $\begin{array}{c}-0.0188 \\
{[0.71]} \\
\end{array}$ & $\begin{array}{l}0.0808 \\
{[1.51]} \\
\end{array}$ & $\begin{array}{c}0.0439 \\
{[1.09]} \\
\end{array}$ & $\begin{array}{r}0.0268 \\
{[0.71]} \\
\end{array}$ & $\begin{array}{c}0.0237 \\
{[0.79]}\end{array}$ \\
\hline Observations & 45 & 45 & 45 & 51 & 51 \\
\hline R-squared & 0.36 & 0.61 & 0.49 & 0.55 & 0.55 \\
\hline DW-statistic (transformed) & 1.88 & 2.30 & 1.67 & 1.77 & 1.76 \\
\hline DW-statistic (original) & 2.02 & 2.94 & 1.33 & 1.69 & 1.69 \\
\hline
\end{tabular}

Notes: Absolute value of t statistics in brackets; * significant at 10\%; ** significant at 5\%; *** significant at $1 \%$ 
Table 6: Regression Results. Prais Winsten estimator with robust standard errors.

\section{Leftist government.}

\section{Interaction with 1991-2007 decadal dummy.}

Dependent variable: growth rate of the Revenues from Contributions, Tax-financed subsidies and expenditures for Pension benefits of the German Pension Insurance (as a share of GDP) 1957-2007 and expenditures for public healthcare benefits of the German Public Health Insurance (per member of the German Public Health Insurance, Euros, constant prices) 19512007.

\begin{tabular}{|c|c|c|c|c|c|}
\hline & $\begin{array}{c}\text { (1) } \\
\Delta \ln \\
\text { Contributions }\end{array}$ & $\begin{array}{c}(2) \\
\Delta \ln \\
\text { Tax-financed } \\
\text { subsidies } \\
\end{array}$ & $\begin{array}{c}(3) \\
\Delta \ln \\
\text { Pension } \\
\text { benefits }\end{array}$ & $\begin{array}{c}(4) \\
\Delta \ln \\
\text { Healthcare } \\
\text { benefits } \\
\end{array}$ & $\begin{array}{c}\qquad(5) \\
\Delta \ln \\
\text { Healthcare } \\
\text { benefits }\end{array}$ \\
\hline Election & $\begin{array}{c}-0.0096 \\
{[0.92]}\end{array}$ & $\begin{array}{c}0.0369 \\
{[1.30]}\end{array}$ & $\begin{array}{c}0.0018 \\
{[0.16]}\end{array}$ & $\begin{array}{c}0.0188 \\
{[1.08]}\end{array}$ & $\begin{array}{l}0.0216 \\
{[1.15]}\end{array}$ \\
\hline Left & $\begin{array}{c}-0.0012 \\
{[0.33]}\end{array}$ & $\begin{array}{l}0.0003 \\
{[0.04]}\end{array}$ & $\begin{array}{c}-0.0018 \\
{[0.31]}\end{array}$ & $\begin{array}{c}-0.0019 \\
{[0.16]}\end{array}$ & $\begin{array}{l}0.0021 \\
{[0.26]}\end{array}$ \\
\hline Dummy 1991-2007 & $\begin{array}{c}0.0021 \\
{[0.30]}\end{array}$ & $\begin{array}{c}0.0210 * \\
{[1.93]}\end{array}$ & $\begin{array}{c}0.0146 \\
{[1.53]}\end{array}$ & $\begin{array}{c}-0.0177 \\
{[1.14]}\end{array}$ & $\begin{array}{c}-0.0131 \\
{[1.17]}\end{array}$ \\
\hline Left* Dummy 1991-2007 & $\begin{array}{c}-0.0084^{*} \\
{[1.83]}\end{array}$ & $\begin{array}{c}-0.0158 * * \\
{[2.12]}\end{array}$ & $\begin{array}{l}-0.003 \\
{[0.46]}\end{array}$ & $\begin{array}{c}-0.0116 \\
{[1.40]}\end{array}$ & $\begin{array}{c}-0.0135^{*} \\
{[1.84]}\end{array}$ \\
\hline$\Delta$ ln Unemployment & $\begin{array}{l}0.0016 \\
{[0.10]}\end{array}$ & $\begin{array}{c}0.2041 * * * \\
{[5.10]}\end{array}$ & $\begin{array}{c}0.1036 * * * \\
{[4.01]}\end{array}$ & & \\
\hline$\Delta \ln$ Compensation of Employees & $\begin{array}{l}0.1498 \\
{[0.90]}\end{array}$ & $\begin{array}{c}-0.9115^{* *} \\
{[2.24]}\end{array}$ & $\begin{array}{c}-0.1842 \\
{[0.72]}\end{array}$ & & \\
\hline$\Delta \ln$ Dependency ratio & $\begin{array}{l}0.4242 \\
{[1.32]}\end{array}$ & $\begin{array}{c}0.6352 \\
{[1.04]}\end{array}$ & $\begin{array}{c}0.1839 \\
{[0.54]}\end{array}$ & $\begin{array}{l}0.8896 \\
{[1.54]}\end{array}$ & $\begin{array}{l}0.8422 \\
{[1.54]}\end{array}$ \\
\hline Linear time trend & $\begin{array}{c}-0.0001 \\
{[0.22]}\end{array}$ & $\begin{array}{c}-0.0025^{* *} \\
{[2.09]}\end{array}$ & $\begin{array}{c}-0.0015 \\
{[1.66]}\end{array}$ & & \\
\hline Divided Government & & & & $\begin{array}{c}0.0158 \\
{[0.55]}\end{array}$ & \\
\hline$\Delta \ln$ GDP per member & & & & $\begin{array}{c}0.7754 * * \\
{[2.21]}\end{array}$ & $\begin{array}{c}0.8077 * * \\
{[2.47]}\end{array}$ \\
\hline$\Delta \ln$ Mortality rate & & & & $\begin{array}{l}0.5801 \\
{[1.67]}\end{array}$ & $\begin{array}{c}0.5857^{*} \\
{[1.70]}\end{array}$ \\
\hline$\Delta \ln$ Linear time trend & & & & $\begin{array}{l}-0.007 \\
{[0.08]}\end{array}$ & $\begin{array}{l}0.0464 \\
{[0.72]}\end{array}$ \\
\hline Unification Dummy & $\begin{array}{c}0.0125 \\
{[0.92]}\end{array}$ & $\begin{array}{c}0.0568 \\
{[1.06]}\end{array}$ & $\begin{array}{l}0.0042 \\
{[0.21]}\end{array}$ & $\begin{array}{c}0.0624 \\
{[0.85]}\end{array}$ & $\begin{array}{l}0.0681 \\
{[0.97]}\end{array}$ \\
\hline Constant & $\begin{array}{c}-0.0072 \\
{[0.26]} \\
\end{array}$ & $\begin{array}{c}0.1223 * * \\
{[2.05]}\end{array}$ & $\begin{array}{l}0.0593 \\
{[1.42]} \\
\end{array}$ & $\begin{array}{c}0.0185 \\
{[0.65]} \\
\end{array}$ & $\begin{array}{c}0.0178 \\
{[0.64]}\end{array}$ \\
\hline Observations & 45 & 45 & 45 & 51 & 51 \\
\hline R-squared & 0.39 & 0.62 & 0.5 & 0.56 & 0.55 \\
\hline DW-statistic (transformed) & 1.92 & 2.24 & 1.66 & 1.75 & 1.75 \\
\hline DW-statistic (original) & 2.08 & 2.98 & 1.35 & 1.69 & 1.68 \\
\hline
\end{tabular}

Notes: Absolute value of $t$ statistics in brackets; $*$ significant at $10 \% ; * *$ significant at $5 \% ; * * *$ significant at $1 \%$ 
Table A1: Descriptive Statistics.

\begin{tabular}{|c|c|c|c|c|c|c|}
\hline Variable & Obs. & Mean & Std. Dev. & Min & Max & Source \\
\hline $\begin{array}{l}\text { Contributions to the German } \\
\text { Pension system } \\
\text { (as a share of GDP) }\end{array}$ & 51 & 6.62 & 1.11 & 4.50 & 7.94 & $\begin{array}{l}\text { German Pension Insurance and } \\
\text { German Federal Statistical } \\
\text { Office }\end{array}$ \\
\hline $\begin{array}{l}\text { Tax-financed pension revenues } \\
\text { (as a share of GDP) }\end{array}$ & 51 & 1.51 & 0.43 & 0.87 & 2.49 & $\begin{array}{l}\text { German Pension Insurance and } \\
\text { German Federal Statistical } \\
\text { Office }\end{array}$ \\
\hline $\begin{array}{l}\text { Pension benefits } \\
\text { (as a share of GDP) }\end{array}$ & 51 & 6.91 & 1.37 & 4.65 & 9.01 & $\begin{array}{l}\text { German Pension Insurance and } \\
\text { German Federal Statistical } \\
\text { Office }\end{array}$ \\
\hline $\begin{array}{l}\text { Healthcare benefits } \\
\text { (per member) }\end{array}$ & 57 & 1045.58 & 1020.52 & 16.96 & 3199.65 & $\begin{array}{l}\text { German Federal Ministry of } \\
\text { Public Health and German } \\
\text { Federal Statistical Office }\end{array}$ \\
\hline Election & 57 & 0.26 & 0.44 & 0 & 1 & own collection \\
\hline Left & 52 & 0.38 & 0.49 & 0 & 1 & own collection \\
\hline CDU/FDP & 57 & 0.56 & 0.50 & 0 & 1 & own collection \\
\hline CDU/SPD & 57 & 0.09 & 0.29 & 0 & 1 & own collection \\
\hline SPD/FDP & 57 & 0.23 & 0.42 & 0 & 1 & own collection \\
\hline SPD/GREEN & 57 & 0.12 & 0.33 & 0 & 1 & own collection \\
\hline Divided Government & 57 & 0.70 & 0.46 & 0 & 1 & Leunig and Bauer (2006) \\
\hline Unemployment rate & 57 & 6.35 & 4.02 & 0.7 & 12.7 & $\begin{array}{l}\text { German Federal Statistical } \\
\text { Office }\end{array}$ \\
\hline Compensation of Employees & 51 & 13554.23 & 10934.61 & 783.71 & 33694.88 & $\begin{array}{l}\text { Research Group } \\
\text { "Volkswirtschaftliche } \\
\text { Gesamtrechnung der Länder" }\end{array}$ \\
\hline Dependency ratio & 57 & 23.52 & 4.19 & 16 & 33.2 & German Pension Insurance \\
\hline $\begin{array}{l}\text { GDP, real (per health insurance } \\
\text { member) }\end{array}$ & 57 & 18086.03 & 16306.11 & 802.67 & 53717.65 & $\begin{array}{l}\text { German Federal Ministry of } \\
\text { Public Health and German } \\
\text { Federal Statistical Office }\end{array}$ \\
\hline Mortality rate & 57 & 11.43 & 0.78 & 9.9 & 12.6 & $\begin{array}{l}\text { German Federal Statistical } \\
\text { Office }\end{array}$ \\
\hline Linear time trend & 57 & 30.00 & 16.60 & 2 & 58 & own collection \\
\hline Unification dummy & 57 & 0.02 & 0.13 & 0 & 1 & own collection \\
\hline Trade (as a share of GDP) & 57 & 0.40 & 0.11 & 0.24 & 0.72 & $\begin{array}{l}\text { German Federal Statistical } \\
\text { Office }\end{array}$ \\
\hline
\end{tabular}

